\title{
Diffusible Signal Factor-Mediated Quorum Sensing Plays a Central Role in Coordinating Gene Expression of Xanthomonas citri subsp. citri
}

\author{
Yinping Guo, ${ }^{1}$ Yanping Zhang, ${ }^{2}$ Jian-Liang $\mathrm{Li}^{3}{ }^{3}$ and Nian Wang ${ }^{1}$ \\ ${ }^{1}$ Citrus Research and Education Center, Department of Microbiology and Cell Sciences, University of Florida, 700 Experiment \\ Station Road, Lake Alfred 33850, U.S.A.; ${ }^{2}$ Interdisplinary Center for Biotechnology Research, University of Florida, \\ Gainesville 32611, U.S.A.; ${ }^{3}$ Sanford|Burnham Medical Research Institute at Lake Nona, 6400 Sanger Road, Orlando, \\ FL 32827, U.S.A.
}

Submitted 9 July 2011. Accepted 4 October 2011.

\begin{abstract}
Diffusible signal factor (DSF) family signal-mediated quorum sensing (QS) has been identified in many gramnegative bacteria. This QS pathway of Xanthomonas spp. consists of three major QS components: RpfF, RpfC, and RpfG. The $r p f F$ gene encodes a putative enoyl-CoA hydratase that catalyzes the synthesis of the signal molecule. RpfC and RpfG serve as a two-component system for the perception and transduction of the extracellular DSF family signals. In order to further characterize the QS regulatory network in Xanthomonas citri subsp. citri, we investigated the RpfF, RpfC, and RpfG regulons by using transcriptome analyses. Comparison of the transcriptomes of the QS mutants (rpfF, rpfC, and $r p f G$ ) with that of the wild-type strain revealed a core group of genes controlled by all three QS components, suggesting that the RpfC-RpfG two-component system is a major and conserved signal perception and transduction system for DSF family signal-mediated QS in $X$. citri subsp. citri. The unique genes controlled by RpfF alone indicate the complexity of the QS pathway and the involvement of additional sensory mechanisms in $X$. citri subsp. citri. The unique genes controlled by $\mathrm{RpfC}$ and $\mathrm{RpfG}$, respectively, support the possibility that $\mathrm{RpfC}$ and RpfG play broader roles in gene regulation other than transduction of DSF signals.
\end{abstract}

Quorum sensing (QS) is a sophisticated mechanism allowing bacteria to communicate via the exchange of chemical signals and to alter their behavior on a population-wide scale. It was first found in Vibrio fischeri as a mechanism that controls bioluminescence production based on the local bacterial density (Nealson and Hastings 1979). Since this discovery, QS has been identified in many gram-negative and gram-positive microorganisms (Waters and Bassler 2005). QS bacteria produce and release diffusible chemical signaling molecules into their environment. When the concentration of signaling molecules reaches a threshold, the bacteria detect and respond to these signals, altering their gene expression and thereby regulating a diverse range of physiological activities.

Corresponding author: N. Wang; Telephone: (863) 956-1151; Fax: (863) 956-4631; E-mail: nianwang @ufl.edu

* The $\boldsymbol{e}$-Xtra logo stands for "electronic extra" and indicates that six supplementary tables and six supplementary figures are published online.
In gram-negative bacteria, besides the well-characterized AHL-type of QS signals and AI-2, the diffusible signal factor (DSF) family signals have recently been detected in a variety of bacterial species, including Xanthomonas campestris pv. campestris, X. oryzae pv. oryzae, Xylella fastidiosa, Stenotrophomonas maltophilia, and Burkholderia cenocepacia (Barber et al. 1997; Boon et al. 2008; Colnaghi Simionato et al. 2007; Fouhy et al. 2007; He et al. 2010). Distinct DSF family molecules can be produced by different bacterial species. For instance, a DSF from Xanthomonas campestris pv. campestris has been characterized as cis-11-methyl-2-dodecenoic acid while a DSF-like signal molecule, designated BDSF, has been characterized as cis-2-dodecenoic acid in B. cenocepacia (Boon et al. 2008; Wang et al. 2004). Notably, multiple DSF family molecules can also be produced by one organism; for example, $X$. oryzae pv. oryzae produces three DSF family signals: DSF, BDSF, and cis,cis-11-methyldodeca-2,5-dienoic acid (CDSF) in rich media (He et al. 2010).

DSF signal-mediated QS was first discovered in a mutagenesis analysis to identify genes involved in the regulation of the synthesis of extracellular enzymes in X. campestris pv. campestris (Barber et al. 1997). RpfF functioning as a putative enoylCoA hydratase is a key enzyme for DSF biosynthesis, while the two-component system RpfC-RpfG is involved in sensing and transduction of the DSF signal in $X$. campestris pv. campestris (Barber et al. 1997; He et al. 2006a; Slater et al. 2000). Recent studies revealed the presence of rpfF homologs in xanthomonads, X. fastidiosa, S. maltophilia, and B. cenocepacia (Boon et al. 2008; da Silva et al. 2002; Fouhy et al. 2007; Newman et al. 2004). RpfF from S. maltophilia is essential for the biosynthesis of DSF and seven structurally related fatty acids, and $\mathrm{RpfF}$ from $X$. oryzae pv. oryzae is required for the production of three DSF family signals (DSF, BDSF, and CDSF) (He et al. 2010; Huang and Wong 2007). In addition to RpfF, the well-characterized DSF sensory system RpfC-RpfG of X. campestris pv. campestris is also found in all xanthomonads.

Transcriptome analysis of the $\mathrm{RpfF}$ regulon has significantly advanced the understanding of the DSF-mediated QS regulons in bacteria. One pioneer study conducted by Zhang and colleagues (He et al. 2006b) investigated the QS regulon of $X$. campestris pv. campestris using whole-genome-wide microarray analysis to compare the gene expression patterns of the wildtype strain and its DSF-deficient mutant as well as those of the DSF-deficient mutant in the presence or absence of DSF signals. In that study, 165 genes were identified as belonging to the QS regulon; these were classified into 12 functional groups, includ- 
ing genes encoding extracellular enzymes and genes involved in exopolysaccharide production, flagellum synthesis, resistance to toxins and oxidative stress, and aerobic respiration ( $\mathrm{He}$ et al. 2006b). A later study utilizing proteomic analysis of the wildtype and an $r p f F$ mutant strain revealed that 48 proteins were differentially regulated by QS in $X$. oryzae pv. oryzicola, of which 18 proteins were identified by mass spectrometry as being putatively involved in nitrogen transfer, protein folding, resistance to oxidative stress, and flagellar synthesis (Zhao et al. 2011). However, considering the complicated QS signal transduction cascade, a comprehensive understanding of the RpfC and RpfG regulons is lacking. In this study, we aimed at further advancing our understanding of the QS regulatory network by characterizing the regulons of the DSF signaling pathway components RpfF, RpfC, and RpfG in the important model pathogen $X$. citri subsp. citri through transcriptome analyses.

X. citri subsp. citri (syn. X. citri, X. campestris pv. citri, or $X$. axonopodis pv. citri) is the causal agent of the Asiatic form of citrus canker (Cubero and Graham 2002; Schaad et al.
2006; Vauterin et al. 1995). The Asiatic form (or A type) of citrus canker is the most virulent of all of the strains that cause citrus canker, and it affects the widest range of hosts, including Citrus spp. and many closely related rutaceous plants. $X$. citri subsp. citri enters host plant tissues through stomata and wounds and grows in the intercellular spaces of the spongy mesophyll (Graham et al. 2004). Comparative genomic analysis has revealed that $X$. citri subsp. citri genome contains an $r p f$ locus highly similar to that of $X$. campestris pv. campestris, including $r p f F, r p f C$, and $r p f G$ (da Silva et al. 2002). Though the putative DSF-like signal produced by $X$. citri subsp. citri has not been yet characterized, several pieces of experimental evidence suggest that $X$. citri subsp. citri may employ a DSF signaling mechanism similar to that of $X$. campestris pv. campestris. i) Similar to the phenotypes of the $\operatorname{rpf} F$ and $r p f C$ mutants of $X$. campestris pv. campestris, molecular genetic analysis revealed that the mutations of $r p f F$ and $r p f C$ in $X$. citri subsp. citri reduced the production of extracellular enzymes and compromised the virulence on the host lemon leaves
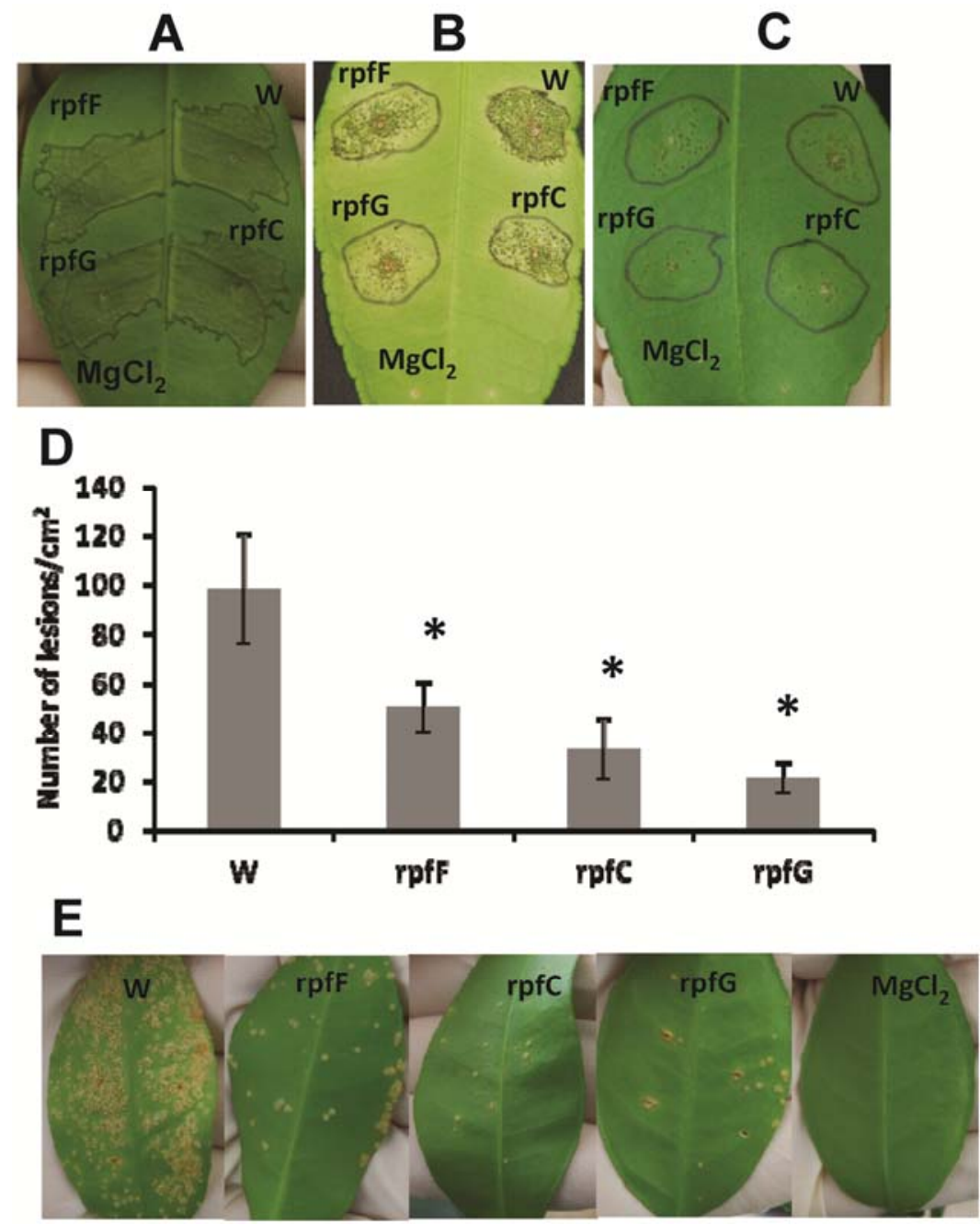

Fig. 1. Virulence of Xanthomonas citri subsp. citri in planta is impaired by mutations in $r p f F, r p f C$, and $r p f G$. A, Representative Duncan grapefruit leaf from four replicates was inoculated with bacterial solutions $\left(10^{8} \mathrm{CFU} / \mathrm{ml}\right)$ and photographed at 6 days postinoculation (DPI); B, representative Duncan grapefruit leaf from four replicates was inoculated with bacterial solutions $\left(10^{5} \mathrm{CFU} / \mathrm{ml}\right)$ and photographed at $18 \mathrm{DPI}$; $\mathbf{C}$, representative Duncan grapefruit leaf from four replicates was inoculated with bacterial solutions $\left(10^{4} \mathrm{CFU} / \mathrm{ml}\right)$ and photographed at $18 \mathrm{DPI}$; D, quantification of canker lesions in Duncan grapefruit leaves inoculated with bacteria $\left(10^{4} \mathrm{CFU} / \mathrm{ml}\right)$ at $18 \mathrm{DPI}$. Error bars represent standard deviation. The PROC GLM procedure of SAS 9.2 was used to analyze the statistical significance of difference in virulence among the strains; ${ }^{*}$, significant difference $(P<0.01)$ in virulence between the mutants and the wildtype strain. The difference in virulence among the mutants was also tested. The $r p f G$ mutant was significantly less virulent than the $r p f C$ mutant $(P<0.05)$ and significantly less virulent than the $r p f F$ mutant $(P<0.01)$. In contrast, the $r p f C$ and $r p f F$ mutants did not show difference in virulence from each other $(P<$ 0.05). Three independent assays were performed with ten leaves each time. E, Spray inoculation of $X$. citri subsp. citri strains on the abaxial side of Duncan grapefruit leaves. Inoculated leaves were photographed at 20 DPI. A $10 \mathrm{mM} \mathrm{MgCl} 2$ solution was used as the mock inoculation control. The assay was repeated three times with five plants each time with similar results, and only one representative result is presented. 
(Siciliano et al. 2006). ii) The $r p f F$ mutant of $X$. citri subsp. $c i$ tri is DSF deficient whereas the rpfC mutant of $X$. citri subsp. citri is DSF hyperproducing, reminiscent of their counterparts in $X$. campestris pv. campestris (Siciliano et al. 2006). The yeast two-hybrid and in vitro biochemical assays showed the direct physical interaction of $\mathrm{RpfF}$ and $\mathrm{RpfC}$ in $X$. citri subsp. citri (Andrade el at. 2006). These findings suggest that $X$. citri subsp. citri uses an autoregulation mechanism similar to that of $X$. campestris pv. campestris to control DSF biosynthesis. iii) The protein-protein interaction analysis revealed that $X$. citri subsp. citri RpfC interacts with RpfG and the HD-GYP domain of RpfG directly interacts with a few GGDEF domaincontaining proteins, which produce the second messenger molecule c-di-GMP, suggesting that the RpfC-RpfG two-component system links DSF signaling with the c-di-GMP signaling pathway (Andrade el at. 2006).

Though these genomic and functional genomic approaches advanced the studies of DSF family signal-mediated QS and provided detailed information about the signaling pathway, the newly discovered findings raise many fundamental questions. i) Because multiple DSF family signals can be produced by a single organism, are there DSF family synthases beyond RpfF? ii) Are there additional DSF signal perception and transduction systems in X. citri subsp. citri? iii) Does the RpfC-RpfG system sense and respond to signals other than DSF family signals?
In this study, a whole-genome microarray was employed to investigate the DSF family signal-mediated QS regulon of $X$. citri subsp. citri by characterizing the RpfF, RpfC, and RpfG regulons. We also investigated the roles of DSF family signalmediated QS in the citrus canker disease cycle and its involvement in early attachment and in planta growth of $X$. citri subsp. citri in the citrus host.

\section{RESULTS}

Generation of the $r p f F, r p f C$, and $r p f G$ mutants of $X$. citri subsp. citri.

To investigate the role of DSF family signal-mediated QS in citrus canker infection, deletion mutants of the three critical genes involved in DSF family signal synthesis, detection, and transduction-rpfF, $r p f C$, and $r p f G$ - were generated using double cross-over recombination (Supplementary Fig. S1). The deletions were confirmed with sequence analysis of the corresponding polymerase chain reaction (PCR) products. The $r p f F$, $r p f C$, and $r p f G$ mutants cannot form compact pellets, unlike the wild-type strain, when centrifuged from the liquid medium nutrient broth (NB) or XVM2 (Supplementary Fig. S2). To confirm the mutations in the QS pathway, the $r p f F, r p f C$, and $r p f G$ mutants were assayed for motility and extracellular protease production, which are well-known phenotypes controlled by
A
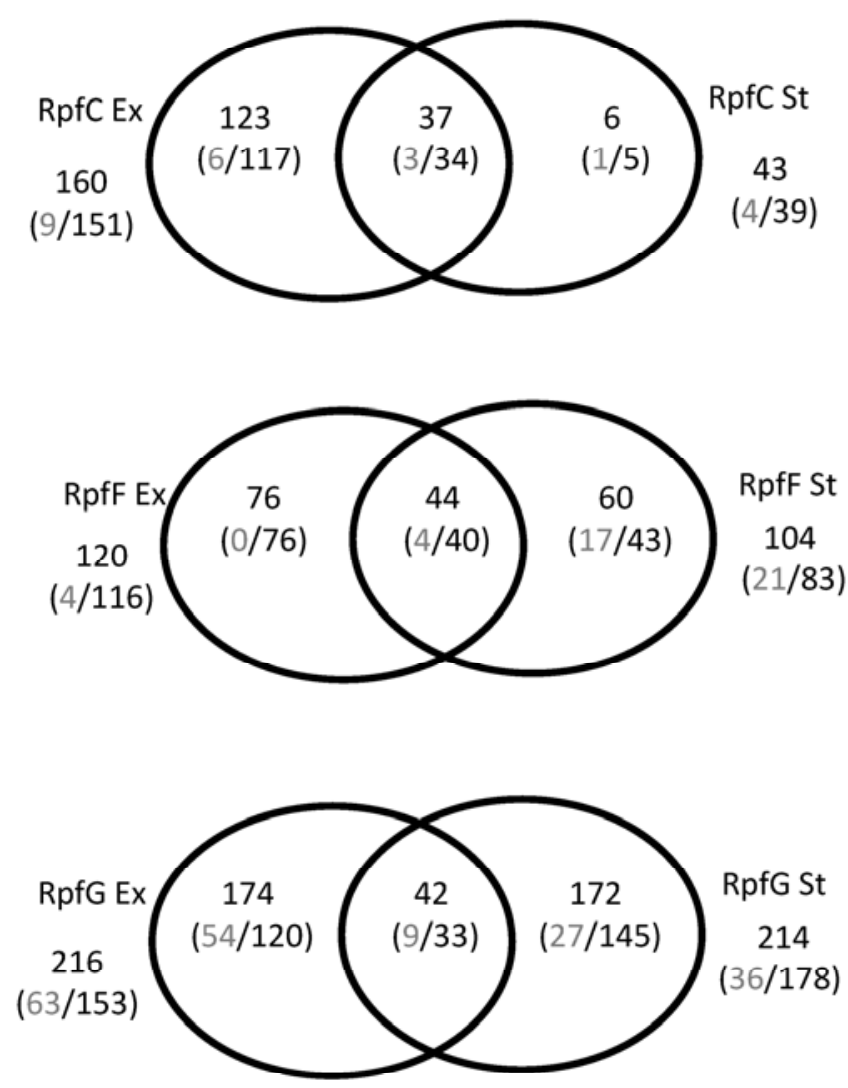

(down-regulated /up-regulated)
B
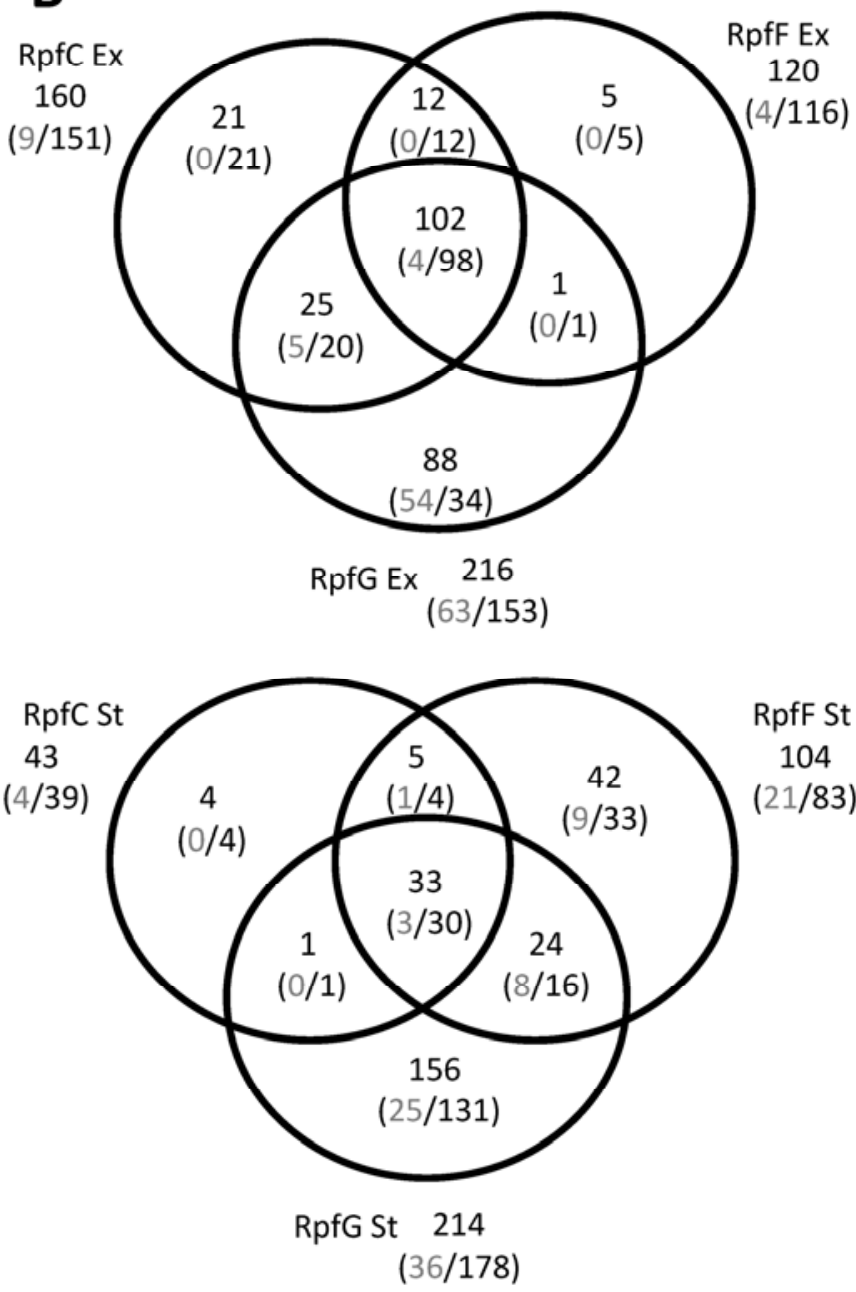

Fig. 2. Venn diagrams showing the overlap of genes whose expression is influenced by RpfF, RpfC, and RpfG in different growth phases. A, Influence of growth phase on the RpfF, RpfC, and RpfG regulons. B, Comparisons of the three regulons in each growth phase. Ex, the exponential phase; St, the stationary phase. Numerals in gray represent the number of genes down-regulated by RpfF, RpfC, or RpfG; numerals in black indicate the number of genes up-regulated by RpfF, RpfC, or RpfG. 
DSF-mediated QS (Barber et al. 1997; Ryan et al. 2006). The $r p f F, r p f C$, and $r p f G$ mutants showed a significant decrease in the production of proteases (Supplementary Fig. S3) and had decreased motility (Supplementary Fig. S4). The phenotypes of all three mutants were restored to the wild-type level following complementation with the corresponding genes in trans.

\section{QS is required for the full virulence}

\section{of $X$. citri subsp. citri in the citrus host.}

The role of QS in the growth of $X$. citri subsp. citri in planta was evaluated by monitoring the populations of the wild-type and $r p f F, r p f C$, and $r p f G$ mutants in, as well as their effects on, Duncan grapefruit, which is a susceptible host for $X$. citri subsp. citri. The wild-type and $r p f F, r p f C$, and $r p f G$ mutants were infiltrated into young leaves of Duncan grapefruit at the starting concentration of $10^{8} \mathrm{CFU} / \mathrm{ml}$. No difference was observed with respect to the time to appearance of lesions or the magnitude of lesions (Fig. 1A). When $10^{5} \mathrm{CFU} / \mathrm{ml}$ was used as the starting concentration, the $r p f F, r p f C$, and $r p f G$ mutants produced fewer lesions than the wild-type (Fig. 1B). However, the cell densities of the mutants in planta were not significantly lower than those of the wild-type strain (data not shown). To quantify the difference in virulence between the $r p f F, r p f C$, and $r p f G$ mutants and the wild-type, we used $10^{4} \mathrm{CFU} / \mathrm{ml}$ to inoculate Duncan grapefruit leaves, photographed the inoculated leaves at 18 days postinoculation (DPI), and then calculated the lesion number per square centimeter. The value of lesion numbers caused by the $r p f F$, rpfC, and $r p f G$ mutants was 50, 32, and $20 \%$ of that caused by the wild-type strain, respectively, in an area of $1 \mathrm{~cm}^{2}$ (Fig. $1 \mathrm{C}$ and D). Deletion of the $r p f F, r p f C$, and $r p f G$ genes significantly reduced the number of lesions formed in Duncan grapefruit leaves $(P<0.01)$. Furthermore, based on these lesion

Table 1. Genes in the RpfF, RpfC, and RpfG regulons (core group) and in any two of the regulons in the exponential phase

\begin{tabular}{|c|c|c|c|c|c|c|}
\hline \multirow[b]{2}{*}{ Locus tag ${ }^{b}$} & \multicolumn{3}{|c|}{$\log _{2}$-fold change ${ }^{a}$} & \multirow[b]{2}{*}{ Gene } & \multirow[b]{2}{*}{ Description } & \multirow[b]{2}{*}{ JCVI $^{\mathrm{c}}$} \\
\hline & rpfC/W Ex & rpfF/W Ex & $\overline{\text { rpfG/W Ex }}$ & & & \\
\hline \multicolumn{7}{|l|}{ Core group } \\
\hline XAC 1427 & -1.57 & -1.36 & -1.36 & pru & Protein U & Cell envelope \\
\hline XAC3921 & -1.24 & -1.01 & -1.29 & ugt & Glucosyltransferase & Cell envelope \\
\hline XAC0661 & -1.05 & -1.07 & -1.99 & peh-1 & Endopolygalacturonase & Cell envelope \\
\hline XAC3524 & 2.77 & 2.54 & 2.49 & - & Hypothetical protein & Cell envelope \\
\hline XAC1976 & -2.50 & -2.44 & -1.15 & $f l g L$ & Flagellar hook-associated protein FlgL & Cellular processes \\
\hline XAC1931 & -2.25 & -1.57 & -1.29 & cheZ & Chemotaxis-related protein & Cellular processes \\
\hline XAC1932 & -2.14 & -1.55 & -1.42 & cheY & Chemotaxis protein & Cellular processes \\
\hline $\mathrm{XAC} 2448$ & -2.11 & -2.09 & -2.00 & $m c p$ & Chemotaxis protein & Cellular processes \\
\hline $\mathrm{XAC} 2866$ & -2.10 & -2.10 & -2.19 & $m c p$ & Chemotaxis protein & Cellular processes \\
\hline XAC1973 & -1.84 & -1.81 & -2.10 & fliS & Flagellar protein & Cellular processes \\
\hline XAC2865 & -1.77 & -1.50 & -1.87 & cheA & Chemotaxis histidine protein kinase & Cellular processes \\
\hline XAC1904 & -1.77 & -1.54 & -1.90 & cheY & Chemotaxis response regulator & Cellular processes \\
\hline XAC2867 & -1.75 & -1.62 & -1.80 & cheW & Chemotaxis protein & Cellular processes \\
\hline XAC1996 & -1.73 & -1.70 & -1.98 & $m c p$ & Chemotaxis protein & Cellular processes \\
\hline XAC1974 & -1.73 & -1.53 & -1.92 & fliD & Flagellar protein & Cellular processes \\
\hline XAC3132 & -1.71 & -1.55 & -2.01 & $m c p$ & Chemotaxis protein & Cellular processes \\
\hline $\mathrm{XAC} 2447$ & -1.67 & -1.30 & -1.60 & cheW & Chemotaxis protein & Cellular processes \\
\hline XAC1930 & -1.66 & -1.30 & -1.03 & cheA & Chemotaxis-related protein & Cellular processes \\
\hline XAC4029 & -1.65 & -1.35 & -1.78 & catB & Catalase precursor & Cellular processes \\
\hline XAC1987 & -1.64 & -1.44 & -1.85 & cheV & Chemotaxis protein & Cellular processes \\
\hline XAC 1893 & -1.64 & -1.70 & -1.70 & $t s r$ & Chemotaxis protein & Cellular processes \\
\hline XAC 1950 & -1.60 & -1.58 & -1.61 & fliJ & Flagellar FliJ protein & Cellular processes \\
\hline XAC1895 & -1.57 & -1.56 & -1.83 & $t s r$ & Chemotaxis protein & Cellular processes \\
\hline XAC1951 & -1.54 & -1.30 & -1.47 & fliI & Flagellar protein & Cellular processes \\
\hline XAC1897 & -1.53 & -1.59 & -1.65 & $t s r$ & Chemotaxis protein & Cellular processes \\
\hline XAC1899 & -1.44 & -1.52 & -1.58 & $t s r$ & Chemotaxis protein & Cellular processes \\
\hline XAC1903 & -1.42 & -1.33 & -1.69 & cheA & Chemotaxis protein & Cellular processes \\
\hline XAC1894 & -1.42 & -1.37 & -1.66 & $t s r$ & Chemotaxis protein & Cellular processes \\
\hline XAC0064 & -1.41 & -1.39 & -1.13 & - & Acetyltransferase & Cellular processes \\
\hline XAC 1907 & -1.41 & -1.11 & -1.65 & parA & Chromosome partitioning protein & Cellular processes \\
\hline XAC 1953 & -1.41 & -1.24 & -1.81 & fliG & Flagellar protein & Cellular processes \\
\hline XAC 1902 & -1.40 & -1.51 & -1.36 & $t s r$ & Chemotaxis protein & Cellular processes \\
\hline $\mathrm{XAC} 1952$ & -1.38 & -1.24 & -1.42 & fliH & Flagellar protein & Cellular processes \\
\hline XAC 3213 & -1.33 & -1.39 & -1.35 & mcpl & Chemotaxis protein & Cellular processes \\
\hline XAC1949 & -1.33 & -1.49 & -1.71 & fliK & Flagellar protein & Cellular processes \\
\hline XAC1896 & -1.25 & -1.12 & -1.24 & $t s r$ & Chemotaxis protein & Cellular processes \\
\hline XAC1954 & -1.23 & -1.05 & -1.74 & fliF & Flagellar MS-ring protein & Cellular processes \\
\hline XAC 1900 & -1.22 & -1.26 & -1.32 & $t s r$ & Chemotaxis protein & Cellular processes \\
\hline XAC1891 & -1.19 & -1.29 & -1.27 & $t s r$ & Chemotaxis protein & Cellular processes \\
\hline XAC0934 & -1.67 & -1.32 & -1.36 & - & Truncated xylanase & Central intermediary \\
\hline XAC0933 & -1.42 & -1.14 & -1.34 & - & Truncated xylanase & Central intermediary \\
\hline XAC 1890 & -1.46 & -1.43 & -1.49 & cheR & Chemotaxis protein methyltransferase & DNA metabolism \\
\hline $\mathrm{XAC} 0612$ & -4.38 & -4.58 & -4.29 & engXCA & Cellulase & Energy metabolism \\
\hline $\mathrm{XAC} 1285$ & -3.34 & -3.31 & -2.56 & $\operatorname{lam} A$ & Endo-1,3- $\beta$-glucanase & Energy metabolism \\
\hline XAC0029 & -3.19 & -3.32 & -3.85 & $e g l$ & Cellulase & $\begin{array}{l}\text { Energy metabolism } \\
\text { (continued on next page) }\end{array}$ \\
\hline
\end{tabular}

${ }^{a} \log _{2}$-fold change was derived from the mutant versus the wild-type strain. Ex, the exponential phase; NS = not significantly differentially expressed $\left(\mid \log _{2}-\right.$ fold change $\mid<1$ or false discovery rate $[\mathrm{FDR}]>0.01$ ).

${ }^{\mathrm{b}}$ Locus tags marked with * represent the extended members of the core group regulated by RpfC, RpfF, and RpfG. These genes showed altered expression with the less stringent cutoff values of $0.585<\mid \log _{2}$-fold change $\mid<1$ and FDR $<0.05$ in the $r p f C, r p f F$, and $r p f G$ mutants as compared with the wild type.

${ }^{c}$ J. Craig Venter Institute (JCVI) functional categories. Central intermediary $=$ central intermediary metabolism; Transport and binding $=$ transport and binding proteins. 
numbers, the $r p f G$ mutant was significantly less virulent than the rpfC mutant $(P<0.05)$ and the rpfF mutant $(P<0.01)$ while the $r p f C$ and $r p f F$ mutants were similar in virulence.

The $r p f F, r p f C$, and $r p f G$ mutants also showed reduced virulence on spray-inoculated grapefruit compared with the wildtype strain. Although they still caused typical canker lesions, the numbers of lesions they caused were much fewer than the wild-type strain (Fig. 1E).

\section{Microarray analysis indicates that RpfF, RpfC, and $\mathrm{RpfG}$ modulate the global gene expression profile of $X$. citri subsp. citri.}

To investigate the role of RpfF, RpfC, and RpfG on the global gene expression profile of X. citri subsp. citri, XVM2 medium was used in this study to mimic the intercellular spaces of plant cells (Wengelnik et al. 1996). The growth of the QS mutants ( $r p f F, r p f C$, and $r p f G)$ and the wild-type strain were monitored in XVM2 (Supplementary Fig. S5). Two time points, 11 and $25 \mathrm{~h}$, were chosen to represent the exponential and stationary phases, respectively. In this study, a false discovery rate (FDR) of 0.01 and an absolute value of $\log _{2}$-fold change of 1.0 (equivalent to fold change of 2.0) were used as the cutoff values. Loss of $r p f C$ caused the differential expression of 160 genes at the exponential phase and 43 genes at the stationary phase (Fig. 2A; Supplementary Table S1). Loss of rpfF caused the alteration in expression of 120 genes at the exponential phase and 104 genes at the stationary phase (Fig. 2A). The deletion of $r p f G$ caused the differential expression of 216 genes at the exponential phase and 214 genes at the stationary phase (Fig. 2A). The microarray data have been confirmed by quantitative reverse-transcription (QRT)-PCR with selected genes (Supplementary Table S2). Overall, 166, 180, and 388

Table 1. (continued from preceding page)

\begin{tabular}{|c|c|c|c|c|c|c|}
\hline \multirow[b]{2}{*}{ Locus tag $^{b}$} & \multicolumn{3}{|c|}{$\log _{2}$-fold change ${ }^{a}$} & \multirow[b]{2}{*}{ Gene } & \multirow[b]{2}{*}{ Description } & \multirow[b]{2}{*}{$\mathrm{JCVI}^{\mathrm{c}}$} \\
\hline & rpfC/W Ex & rpfF/W Ex & rpfG/W Ex & & & \\
\hline XAC0028 & -3.15 & -2.51 & -2.46 & $e g l$ & Cellulase & Energy metabolism \\
\hline XAC1927 & -2.35 & -2.51 & -2.73 & aslB & Fe-S oxidoreductase & Energy metabolism \\
\hline XAC3507 & -1.68 & -2.03 & -1.69 & cels & Truncated cellulase $\mathrm{S}$ & Energy metabolism \\
\hline XAC1975 & -1.58 & -1.79 & -1.71 & fliC & Flagellin & Energy metabolism \\
\hline XAC0446 & -1.26 & -1.00 & -1.19 & $p d h A$ & Pyruvate dehydrogenase E1 $\alpha$ subunit & Energy metabolism \\
\hline XAC1905 & -1.59 & -1.43 & -1.77 & - & Hypothetical protein & Hypothetical proteins \\
\hline XAC3763 & -1.47 & -1.33 & -1.45 & - & Hypothetical protein & Hypothetical proteins \\
\hline XAC1021 & -1.11 & -1.39 & -1.59 & - & Hypothetical protein & Hypothetical proteins \\
\hline XAC1926 & -2.28 & -2.43 & -2.56 & - & Hypothetical protein & Not in JCVI \\
\hline XAC1452 & -2.15 & -2.11 & -2.51 & - & Hypothetical protein & Not in JCVI \\
\hline XAC4026 & -1.91 & -1.74 & -2.29 & - & Hypothetical protein & Not in JCVI \\
\hline XAC4030 & -1.81 & -1.68 & -1.86 & $c a t B$ & Catalase & Not in JCVI \\
\hline XAC1034 & -1.80 & -2.06 & -1.76 & - & Peptidyl-Asp metalloendopeptidase & Not in JCVI \\
\hline XAC3219 & -1.56 & -1.77 & -2.06 & - & Hypothetical protein & Not in JCVI \\
\hline XAC0543 & -1.51 & -1.19 & -1.95 & - & Hypothetical protein & Not in JCVI \\
\hline XAC1928 & -1.49 & -1.32 & -1.66 & - & Hypothetical protein & Not in JCVI \\
\hline XAC3506 & -1.49 & -1.47 & -1.41 & - & Truncated cellulase $S$ & Not in JCVI \\
\hline XAC4091 & -1.40 & -1.66 & -1.56 & - & Hypothetical protein & Not in JCVI \\
\hline XAC3787 & -1.33 & -1.56 & -1.53 & - & Hypothetical protein & Not in JCVI \\
\hline XAC2268 & -1.31 & -1.23 & -1.08 & - & Hypothetical protein & Not in JCVI \\
\hline XAC3533 & -1.31 & -1.63 & -2.18 & - & Hypothetical protein & Not in JCVI \\
\hline XAC1634 & -1.27 & -1.08 & -1.49 & - & Hypothetical protein & Not in JCVI \\
\hline XAC3018 & -1.24 & -1.17 & -1.08 & - & Hypothetical protein & Not in JCVI \\
\hline XAC1972 & -1.22 & -1.21 & -1.19 & - & Hypothetical protein & Not in JCVI \\
\hline XAC0817 & -1.20 & -1.23 & -1.26 & - & Hypothetical protein & Not in JCVI \\
\hline XAC1971 & -1.15 & -1.21 & -1.17 & - & Hypothetical protein & Not in JCVI \\
\hline XAC1778 & -1.15 & -1.18 & -1.34 & - & Sensor kinase & Not in JCVI \\
\hline XAC3523 & 2.06 & 2.00 & 2.33 & - & Hypothetical protein & Not in JCVI \\
\hline XAC3522 & 2.19 & 1.97 & 2.10 & - & Hypothetical protein & Not in JCVI \\
\hline $\mathrm{XAC} 3525$ & 2.98 & 2.65 & 2.54 & - & Hypothetical protein & Not in JCVI \\
\hline $\mathrm{XAC} 2151$ & -4.76 & -4.60 & -4.40 & yapH & YapH protein & Protein fate \\
\hline XAC4182 & -3.16 & -2.88 & -2.87 & - & Cytochrome $\mathrm{C}$ biogenesis protein & Protein fate \\
\hline $\mathrm{XAC} 0465$ & -2.88 & -3.00 & -2.94 & - & Metalloproteinase & Protein fate \\
\hline XAC0540 & -1.76 & -1.90 & -1.58 & - & Ribonuclease & Protein fate \\
\hline XAC2763 & -1.75 & -2.32 & -2.39 & - & Extracellular protease & Protein fate \\
\hline XAC2831 & -1.46 & -1.62 & -1.27 & - & Extracellular serine protease & Protein fate \\
\hline XAC2992 & -2.36 & -2.54 & -2.69 & - & Endoproteinase Arg-C & Protein synthesis \\
\hline XAC2868 & -1.68 & -1.44 & -1.82 & vieA & Response regulator & Regulatory functions \\
\hline XAC3922 & -1.36 & -1.15 & -1.28 & entF & ATP-dependent serine activating enzyme & Regulatory functions \\
\hline XAC3273 & -1.14 & -1.05 & -1.35 & - & Histidine kinase-response regulator hybrid protein & Regulatory functions \\
\hline XAC3769 & -2.37 & -2.82 & -2.59 & $n и с A$ & Endonuclease precursor & Transcription \\
\hline XAC1969 & -1.31 & -1.21 & -1.11 & rpoN & RNA polymerase $\sigma^{54}$ factor & Transcription \\
\hline XAC2864 & -2.42 & -2.16 & -2.50 & - & Hypothetical protein & Transport and binding \\
\hline XAC2853 & -2.98 & -2.99 & -3.80 & - & Cysteine protease & Unclassified \\
\hline XAC3868 & -2.51 & -2.47 & -2.31 & $y l i I$ & Dehydrogenase & Unclassified \\
\hline XAC3014 & -1.59 & -1.62 & -1.27 & $r e b B$ & RebB protein & Unclassified \\
\hline XAC0066 & -1.56 & -1.76 & -1.33 & - & Microcystin dependent protein & Unclassified \\
\hline XAC0067 & -1.46 & -1.66 & -1.27 & $m d p B$ & Microcystin dependent protein & Unclassified \\
\hline XAC0065 & -1.39 & -1.60 & -1.33 & - & Microcystin dependent protein & Unclassified \\
\hline $\mathrm{XAC} 0346$ & -1.31 & -2.00 & -1.88 & - & Degenerated cellulase & Unclassified \\
\hline XAC3016 & -1.29 & -1.36 & -1.19 & rebA & RebA protein & Unclassified \\
\hline \multirow[t]{2}{*}{ XAC3015 } & -1.24 & -1.31 & -1.27 & $\operatorname{rebB}$ & RebB protein & Unclassified \\
\hline & & & & & & (continued on next page) \\
\hline
\end{tabular}


genes were differentially expressed in the $r p f C, r p f F$, and $r p f G$ mutants, respectively, when compared with the wild-type strain (Fig. 2A). Notably, 22.3\% (37 genes), 24.4\% (44 genes), and $10.8 \%$ (42 genes) were found to be regulated in both growth phases by RpfC, RpfF, and RpfG, respectively.

The majority of altered genes were up-regulated by RpfF, RpfC, and RpfG in both growth phases (Fig. 2) based on their lower transcript levels in the mutants compared with the wildtype strain. Functional analysis revealed that the RpfF, RpfG, and RpfC regulons each contained genes in the majority of $\mathrm{J}$. Craig Venter Institute (JCVI)-defined functional categories (Supplementary Fig. S6), indicating that the three QS regulatory components have global effects on gene expression of X. citri subsp. citri.

\section{Comparison of the $\mathrm{RpfF}$, $\mathrm{RpfC}$, and $\mathrm{RpfG}$ regulons in the exponential phase.}

Comparison of the RpfF, RpfC, and RpfG regulons in the exponential phase of growth yielded a comprehensive picture of the DSF family signal-mediated QS pathway. The analysis revealed a core group of 102 genes regulated by RpfF, RpfC, and RpfG (Fig. 2B; Table 1). Two-way comparisons showed further overlap in the repertoire of RpfF-, RpfC-, and RpfGregulated genes, with 12 genes regulated by both $\mathrm{RpfC}$ and RpfF, 25 by both RpfC and RpfG, and 1 by RpfF and RpfG in addition to the core group (Table 1). For each regulon, certain genes were regulated by only one of the three proteins: five genes were regulated by RpfF, 21 by $\mathrm{RpfC}$, and 88 by $\mathrm{RpfG}$ (Fig. 2B).

The conserved core group of genes regulated by all three proteins showed that the alteration of expression was influenced in the same direction by the mutations of QS components. The core group includes 35 genes in cellular processes, with 32 genes involved in chemotaxis and flagellar biosynthesis, such as fliDFGHIJKS. The core group also contains eight genes in energy metabolism, which includes genes involved in the TCA cycle and biosynthesis and degradation of polysaccharides (cellulase and glucanase); six genes involved in determining protein fate (protease); three regulatory genes; the transcription factor $\sigma^{54}$; and a large number of genes encoding hypothetical proteins (Table 1). Among these hypothetical genes, four genes (XAC3522-XAC3525) that were down-regulated

Table 1. (continued from preceding page)

\begin{tabular}{|c|c|c|c|c|c|c|}
\hline \multirow[b]{2}{*}{ Locus tag $^{b}$} & \multicolumn{3}{|c|}{$\log _{2}$-fold change ${ }^{a}$} & \multirow[b]{2}{*}{ Gene } & \multirow[b]{2}{*}{ Description } & \multirow[b]{2}{*}{ JCVI ${ }^{c}$} \\
\hline & rpfC/W Ex & rpfF/W Ex & rpfG/W Ex & & & \\
\hline XAC1906 & -1.21 & -1.13 & -1.40 & cheW & Chemotaxis protein & Unclassified \\
\hline XAC2832 & -1.21 & -1.44 & -1.19 & - & Hypothetical protein & Unclassified \\
\hline XAC3017 & -1.08 & -1.21 & -1.11 & $r e b B$ & RebB protein & Unclassified \\
\hline XAC3314 & -1.84 & -1.75 & -1.32 & - & Hypothetical protein & Unknown function \\
\hline XAC1909 & -1.04 & -1.00 & -1.10 & $\operatorname{mot} C$ & Flagellar motor protein & Cellular processes \\
\hline \multicolumn{7}{|c|}{ RpfC and RpfF only } \\
\hline XAC0611* & -1.28 & -1.04 & NS & $t s r$ & Chemotaxis protein & Cellular processes \\
\hline XAC1982* & -1.68 & -1.32 & NS & $f \lg F$ & Flagellar basal body rod protein FlgF & Cellular processes \\
\hline XAC1983* & -2.04 & -1.64 & NS & $f l g E$ & Flagellar hook protein FlgE & Cellular processes \\
\hline XАC0798* & -1.17 & -1.21 & NS & amy & $\alpha$-Amylase & Energy metabolism \\
\hline $\mathrm{XAC} 1287 *$ & -1.40 & -1.42 & NS & galM & Aldose 1-epimerase & Energy metabolism \\
\hline $\mathrm{XAC} 3562 *$ & -1.35 & -1.22 & NS & pel & Pectate lyase & Energy metabolism \\
\hline XAC4321* & -1.20 & -1.08 & NS & - & Hypothetical protein & Not in JCVI \\
\hline XAC2600 & -1.06 & -1.09 & NS & btuB & TonB-dependent receptor & Transport and binding \\
\hline XAC2830 & -1.04 & -1.15 & NS & fhuA & TonB-dependent receptor & Transport and binding \\
\hline XAC0330 & -1.15 & -1.22 & NS & cmfA & Conditioned medium factor & Unclassified \\
\hline XAC $3019 *$ & -1.20 & -1.10 & NS & - & Hypothetical protein & Unclassified \\
\hline XAC2986* & -1.40 & -1.19 & NS & pelB & Pectate lyase II & Energy metabolism \\
\hline \multicolumn{7}{|c|}{ RpfC and RpfG only } \\
\hline XAC1984* & -1.99 & NS & -1.76 & $f l g D$ & Flagellar basal body rod modification protein & Cell envelope \\
\hline XАC0443* & -1.20 & NS & -1.09 & $p d h B$ & $\begin{array}{l}\text { Branched-chain } \alpha \text {-keto acid dehydrogenase } \\
\text { subunit E2 }\end{array}$ & Cellular processes \\
\hline XAC1978* & -1.81 & NS & -1.55 & flgJ & Flagellar rod assembly protein/muramidase FlgJ & Cellular processes \\
\hline XAC 1979 & -1.84 & NS & -1.87 & flgI & Flagellar basal body P-ring protein & Cellular processes \\
\hline XAC1980 & -1.84 & NS & -1.83 & $f l g H$ & Flagellar basal body L-ring protein & Cellular processes \\
\hline XAC1981 & -1.91 & NS & -1.94 & $f \lg G$ & Flagellar basal body rod protein FlgG & Cellular processes \\
\hline XAC1985 & -1.81 & NS & -1.65 & $f \lg C$ & Flagellar basal body rod protein FlgC & Cellular processes \\
\hline XAC2869* & -1.27 & NS & -1.34 & cheR & Response regulator for chemotaxis & DNA metabolism \\
\hline $\mathrm{XAC} 0445^{*}$ & -1.27 & NS & -1.21 & $p d h B$ & Pyruvate dehydrogenase E1 $\beta$ subunit & Energy metabolism \\
\hline XAC4079* & 1.40 & NS & 1.06 & $e c a A$ & A-type carbonic anhydrase & Energy metabolism \\
\hline XAC0753 & -1.31 & NS & -1.63 & - & Hypothetical protein & Hypothetical proteins \\
\hline $\mathrm{XAC} 1210 *$ & -1.78 & NS & -1.12 & - & Hypothetical protein & Not in JCVI \\
\hline XAC $1810 *$ & 1.23 & NS & 2.35 & - & Hypothetical protein & Not in JCVI \\
\hline XAC $1898 *$ & -1.12 & NS & -1.36 & - & Hypothetical protein & Not in JCVI \\
\hline XAC $1990 *$ & -1.36 & NS & -1.65 & - & Hypothetical protein & Not in JCVI \\
\hline XАC2786* & -1.32 & NS & -1.65 & - & Hypothetical protein & Not in JCVI \\
\hline XAC3926* & 1.24 & NS & 1.57 & - & Hypothetical protein & Not in JCVI \\
\hline XAC1328* & -1.09 & NS & -1.29 & - & Hypothetical protein & Regulatory functions \\
\hline XAC1812* & 1.23 & NS & 2.53 & $h m s F$ & $\mathrm{HmsF}$ protein & Regulatory functions \\
\hline XAC1989* & -1.27 & NS & -1.63 & $f \lg M$ & Flagellar protein & Regulatory functions \\
\hline XAC1993* & -1.08 & NS & -1.34 & - & Hypothetical protein & Regulatory functions \\
\hline $\mathrm{XAC} 2382 *$ & 1.10 & NS & 1.34 & - & GGDEF family protein & Regulatory functions \\
\hline XAC0435* & -1.28 & NS & -1.61 & $\operatorname{virK}$ & VirK protein & Unclassified \\
\hline XAC0350* & -1.01 & NS & -1.30 & - & Hypothetical protein & Unknown function \\
\hline XAC1934* & -1.70 & NS & -1.78 & fleN & Flagellar biosynthesis switch protein & Unknown function \\
\hline \multicolumn{7}{|c|}{ RpfF and RpfG only } \\
\hline XAC1995* & NS & -1.07 & -1.20 & - & Hypothetical protein & Not in JCVI \\
\hline
\end{tabular}


share high identities at the amino acid sequence level with the $x a g A, x a g B, x a g C$, and $x a g D$ genes of $X$. campestris pv. campestris. The $x a g A, x a g B, x a g C$, and $x a g D$ genes have been characterized as being involved in biofilm formation and may contribute to the synthesis of polysaccharide adhesin because they share high similarity to the pgaA, pgaB, pgaC, and pgaD locus of Escherichia coli, which is responsible for adhesin biosynthesis (Tao et al. 2010). The functions of the genes in the conserved core group regulated by the three QS components explained the observation of the alterations in motility and protease production and the pellet phenotype caused by the mutations of $r p f C, r p f F$, and $r p f G$. The findings further supported that $X$. citri subsp. citri uses a DSF family signal-mediated QS mechanism similar to that of $X$. campestris pv. campestris.

We examined the expression of the genes altered in two of the three regulons for alterations in the third based on a less stringent cut-off value; namely, a fold-change of 1.5 (|l $\log _{2}$-fold change $=0.585$ ) and an FDR of 0.05. Most of these genes could be grouped into the core group when using this cut-off value, including 9 of 12 genes shared by the RpfF and RpfC regulons, 20 of 25 genes shared by the RpfC and RpfG regulons, and the 1 gene shared by the RpfF and RpfG regulons (Table 1). The expression of all of these genes was altered in the same direction in all three mutants compared with the wildtype. Therefore, we designated these genes as the extended members of the core group, which includes eight genes associated with chemotaxis and flagellar biosynthesis, six genes involved in energy metabolism (sugar metabolism and pectate lyases for polysaccharides degradation), five regulatory genes, and genes encoding hypothetical proteins. The biological functions of the extended core group are consistent with the functions of genes in the conserved core group, further supporting the idea that the extended members are true members of the core group.

The genes controlled by only one of the three QS components were generally similar regardless of whether the cut-off criteria were an FDR of 0.01 and twofold change or an FDR of 0.05 and a 1.5-fold change (Supplementary Table S3). The genes controlled only by RpfF include fimA encoding type IV pilin, cirA encoding a TonB-dependent receptor, and uahA (XAC4326 and XAC4327) involved in energy metabolism. In addition to the hypothetical genes controlled by $\mathrm{RpfC}$, the unique genes in the RpfC regulon included genes involved in adaptation to the environment, such as katE encoding a catalase, $c z c D$ encoding a heavy metal transporter, and genes encoding oxidoreductases (XAC1178 and XAC3738). RpfG alone regulated 88 genes, including 19 genes involved in transport; four genes encoding a type III secretion system (T3SS) translocon ( $h r c C$, hrpB2, hrcJ, and $h p a B)$; seven genes associated with energy metabolism; and five genes encoding cell surface appendages such as a type $\mathrm{V}$ secretion system adhesin ( $x a d A)$, PGA adhesion ( $h m s H R$ ), and fimbria (pilM). Among the genes encoding transporters controlled by RpfG, 14 genes involved in ferrous transport were down-regulated by RpfG.

\section{Comparison of the $\mathrm{RpfF}$, RpfC, and RpfG regulons in the stationary phase.}

The comparison of the RpfF, RpfC, and RpfG regulons in the stationary phase identified a conserved core group of 33 genes showing differential expression in all three mutants compared with the wild-type (Fig. 2B; Table 2). A two-way comparison revealed an overlap of 5 genes by the RpfC and RpfF regulons, 1 gene by the RpfC and RpfG regulons, and 24 genes by the RpfF and RpfG regulons (Fig. 2B; Table 2). Most of the genes shared by only two regulons could fall into the third regulon based on the less stringent cut-off values described above; these included 4 of 5 genes shared by the RpfF and RpfC regulons, the 1 gene shared by the $\mathrm{RpfC}$ and $\mathrm{RpfG}$ regulons, and 16 of 24 genes shared by the RpfF and RpfG regulons (Table 2). The expression of all of these genes was altered in the same direction compared with the wild-type in all three mutants. Therefore, we considered these genes as the extended members of the core group in the stationary phase. The genes regulated by only one of the three QS components included 4 genes controlled by RpfC, 42 genes by RpfF, and 156 genes by RpfG (Fig. 2B; Supplementary Table S4).

The conserved core group consists of two flagellar genes, one gene encoding catalase ( $k a t E)$, four genes in energy metabolism including two genes encoding cellulases), one regulatory gene, and genes encoding hypothetical proteins (Table 2). In addition to the hypothetical genes, the extended members of the core group include genes involved in flagellar biosynthesis, genes encoding adhesins (HmsFH and XAC3523-3524), and the gene XAC1969 encoding factor $\sigma^{54}$.

Similar to the genes altered in the exponential phase, the genes controlled by only one of the three QS components in the stationary phase were generally similar based on both the low- and high-stringency cut-off criteria described above. The unique genes in the RpfC regulon included two genes involved in energy metabolism and two genes associated with protein fate. The genes regulated only by RpfG included genes associated with the cell envelop such as outer membrane proteins, genes involved in energy metabolism, regulatory genes, genes involved in transcription, genes encoding transporters, and a large number of genes encoding hypothetical proteins. The genes regulated only by RpfF include genes involved in flagellar biosynthesis, virulence genes, regulatory genes, and genes encoding hypothetical proteins.

\section{The attachment of $X$. citri subsp. citri was reduced by the mutations of $r p f F, r p f C$, and $r p f G$.}

Given the significant effect of QS on expression of chemotaxis and flagellar genes as well as genes encoding membrane surface components such as the type IV pilus, we investigated whether QS mediates the bacterial attachment in pathogenesis. First, the wild-type and $r p f F, r p f C$, and $r p f G$ mutants were tested for their early attachment ability on abiotic surfaces (hydrophobic). For all of the mutants, attachment to a hydrophobic surface was significantly reduced compared with the wildtype strain, with the level of crystal violet stain retained similar to that of the negative buffer control (Fig. 3A and B). In addition, the wild-type strain performed better in the attachment assay when grown in XVM2 than in NB.

We also investigated the bacterial attachment to host leaves based on attachment of cells in suspensions to the abaxial surface of Duncan grapefruit leaves. Similar to the results of the attachment to the abiotic surface, the wild-type strain grown in either XVM2 or NB attached to grapefruit leaves and retained crystal violet (CV) staining, whereas the $r p f F, r p f C$, and $r p f G$ mutants were not able to attach to the leaf, and there was no significant difference for the mutants in $\mathrm{CV}$ staining compared with the negative buffer control (Fig. 3C).

To further examine the difference in attachment to leaves by the wild-type and the $r p f F, r p f C$, and $r p f G$ mutants, we used confocal laser-scanning microscopy to observe the green fluorescent protein (GFP)-labeled bacterial cells attached to the leaves. The GFP plasmid did not affect the attachment to abiotic surface and biotic surfaces or the virulence in planta (data not shown). Given the better performance of bacteria grown in XVM2, the GFP-labeled strains were grown in $\mathrm{XVM} 2$ prior to the leaf attachment assay. After $1 \mathrm{~h}$ of incubation, the wild-type cells started to aggregate to microcolonies (Fig. 4A). In contrast, a few individual cells of the $r p f F, r p f C$, and $r p f G$ mutants attached to the leaves (Fig. 4A). After $6 \mathrm{~h}$ of 
incubation, many more wild-type cells attached to the leaves and formed a matrix on the leaves (Fig. 4B and C), whereas the $r p f F, r p f C$, and $r p f G$ mutants formed microcolonies on the leaves (Fig. 4B). Each leaf was scanned at different depths and showed bacteria primarily located in the depression formed by the anticlinal wall of epidermal cells and around stomata, rather than on the top of the periclinal wall of epidermal cells (Fig. 4C). To confirm this observation, we used a scanning electron microscope to examine leaves incubated with bacterial suspensions for $6 \mathrm{~h}$. More wild-type cells than QS mutant cells occupied the depressions between epidermal cells and around stomata (Fig. 4D).

\section{DISCUSSION}

DNA microarrays have been widely used to study the transcriptional responses of many organisms to genetic and environmental perturbations (Dharmadi and Gonzalez 2004; Ye et al. 2001). In the present study, we studied the QS regulon using a whole-genome DNA microarray for $X$. citri subsp. citri 306. The reliability and robustness of this Agilent array have been confirmed in the transcriptome analyses of the HrpG and HrpX regulons in our previous study (Guo et al. 2011). They were further validated in the present study using QRT-PCR.

Transcriptome analysis identified that 180 genes were under the control of RpfF under the conditions tested. Genes in the $\mathrm{RpfF}$ regulon include those involved in chemotaxis and motility, adhesion, stress tolerance, regulation, transport, and detoxifi- cation, which is consistent with the previous findings on the DSF regulon in $X$. campestris pv. campestris (He et al. 2006b). The comparison of the RpfF regulon in the exponential phase and stationary phase revealed that 44 genes overlapped in both phases; these composed only $24.6 \%$ of the RpfF regulon. A similar growth-phase-dependent regulation pattern was shown for the RpfC and RpfG regulons, indicating that regulation of QS in $X$. citri subsp. citri is growth phase-dependent (Fig. 2A), as was shown previously for QS in Pseudomonas aeruginosa (Schuster et al. 2003; Wagner et al. 2003). In P. aeruginosa, some QS-regulated genes showed increased expression in the early exponential or stationary phase but most showed increases in the late exponential to early stationary phase (Schuster et al. 2003). The mechanism for the growth-phase-dependent QS regulation remains to be determined.

Notably, the numbers of genes in the core group controlled by all three QS components varied from the exponential phase to the stationary phase (Fig. 2B). The fewer genes in the core group in the stationary phase compared with in the exponential phase (33 versus 102) may be due to the fewer genes in the RpfC regulon in the stationary phase. Because the $r p f C$ mutant is a DSF family signal-overproducing strain, we hypothesize that the accumulated DSF family signals might bypass the RpfC-RpfG system and be sensed by other two-component systems for gene regulation. This hypothesis is supported by the regulation patterns of $\mathrm{RpfF}, \mathrm{RpfC}$, and RpfG. The expression of $40 \%$ ( 42 genes) of genes in the RpfF regulon was not regulated by RpfC and RpfG in the stationary phase (Fig. 2B),

Table 2. Genes in the RpfF, RpfC, and RpfG regulons (core group) and in any two of the regulons in the stationary phase

\begin{tabular}{|c|c|c|c|c|c|c|}
\hline \multirow[b]{2}{*}{ Locus tag $^{b}$} & \multicolumn{3}{|c|}{$\log _{2}$-fold change ${ }^{a}$} & \multirow[b]{2}{*}{ Gene } & \multirow[b]{2}{*}{ Description } & \multirow[b]{2}{*}{ JCVI $^{\mathrm{c}}$} \\
\hline & rpfC/W St & rpfF/W St & rpfG/W St & & & \\
\hline \multicolumn{7}{|l|}{ Core group } \\
\hline XAC 3524 & 1.24 & 2.01 & 1.14 & - & Hypothetical protein & Cell envelope \\
\hline XAC1178 & -1.89 & -1.95 & -2.63 & - & Oxidoreductase & Cellular processes \\
\hline XAC 1950 & -1.34 & -1.83 & -1.35 & fliJ & Flagellar FliJ protein & Cellular processes \\
\hline XAC 1949 & -1.24 & -1.52 & -1.29 & fliK & Flagellar protein & Cellular processes \\
\hline XAC1211 & -1.44 & -1.51 & -2.20 & katE & Catalase & Cellular processes \\
\hline XAC 3738 & -1.23 & -1.16 & -1.23 & - & Oxidoreductase & Central intermediary \\
\hline XAC0029 & -3.96 & -4.52 & -3.80 & $e g l$ & Cellulase & Energy metabolism \\
\hline XAC0612 & -2.06 & -3.09 & -1.89 & engXCA & Cellulase & Energy metabolism \\
\hline XAC1927 & -1.67 & -2.65 & -3.51 & $a s l B$ & $\mathrm{Fe}-\mathrm{S}$ oxidoreductase & Energy metabolism \\
\hline XAC3747 & -1.27 & -1.29 & -1.85 & $y b d R$ & Zn-dependent alcohol dehydrogenase & Energy metabolism \\
\hline XAC1021 & -1.36 & -1.59 & -1.57 & - & Hypothetical protein & Hypothetical proteins \\
\hline XAC0543 & -2.50 & -2.80 & -2.59 & - & Hypothetical protein & Not in JCVI \\
\hline XAC1926 & -1.50 & -2.55 & -3.52 & - & Hypothetical protein & Not in JCVI \\
\hline XAC3219 & -1.71 & -2.18 & -2.11 & - & Hypothetical protein & Not in JCVI \\
\hline XAC2786 & -1.75 & -2.14 & -1.97 & - & Hypothetical protein & Not in JCVI \\
\hline XAC3533 & -1.88 & -1.74 & -2.11 & - & Hypothetical protein & Not in JCVI \\
\hline $\mathrm{XAC} 1210$ & -1.26 & -1.25 & -1.34 & - & Hypothetical protein & Not in JCVI \\
\hline XAC3513 & -1.36 & -1.20 & -1.38 & - & Hypothetical protein & Not in JCVI \\
\hline XAC3745 & -1.12 & -1.08 & -1.90 & - & Hypothetical protein & Not in JCVI \\
\hline XAC3746 & -1.07 & -1.05 & -1.89 & - & Hypothetical protein & Not in JCVI \\
\hline XAC3522 & 1.11 & 1.77 & 1.10 & - & Hypothetical protein & Not in JCVI \\
\hline XAC 3525 & 2.04 & 2.47 & 1.55 & - & Hypothetical protein & Not in JCVI \\
\hline XAC2992 & -1.97 & -2.58 & -2.55 & - & Endoproteinase Arg-C & Protein synthesis \\
\hline XAC3273 & -1.31 & -1.38 & -1.16 & - & Histidine kinase-response regulator hybrid protein & Regulatory functions \\
\hline XAC3856 & -1.53 & -1.49 & -1.84 & - & Hypothetical protein & Transport and binding \\
\hline $\mathrm{XAC} 2853$ & -3.40 & -4.20 & -4.02 & - & Cysteine protease & Unclassified \\
\hline XAC0346 & -1.84 & -2.42 & -2.07 & - & Degenerated cellulase & Unclassified \\
\hline XAC 3868 & -1.86 & -2.21 & -2.05 & $y l i I$ & Dehydrogenase & Unclassified \\
\hline XAC0435 & -1.77 & -2.14 & -2.03 & $\operatorname{virK}$ & VirK protein & Unclassified \\
\hline \multirow[t]{2}{*}{$\mathrm{XAC} 1177$} & -1.69 & -1.79 & -1.83 & - & Hypothetical protein & Unclassified \\
\hline & & & & & & (continued on next page) \\
\hline
\end{tabular}

${ }^{\mathrm{a}} \log _{2}$-fold change was derived from the mutant versus the wild-type strain. St, the stationary phase; NS = not significantly differentially expressed (|log $2^{-}$ fold change $\mid<1$ or false discovery rate $[$ FDR $]>0.01)$.

${ }^{\mathrm{b}}$ Locus tags marked with * represent the extended members of the core group regulated by RpfC, RpfF, and RpfG. These genes showed altered expression with the less stringent cutoff values of $0.585<\mid \log _{2}$-fold change $\mid<1$ and FDR $<0.05$ in the $r p f C$, rpfF, and $r p f G$ mutants as compared with the wild type.

${ }^{\mathrm{c}} \mathrm{J}$. Craig Venter Institute (JCVI) functional categories. Central intermediary = central intermediary metabolism, Transport and binding $=$ transport and binding proteins, and Mobile = mobile and extrachromosomal element functions. 
suggesting that DSF family signals might be sensed and transduced by additional sensing systems other than the RpfCRpfG system. McCarthy and associates (2010) found that the novel sensor of the DSF family signal BCAM0227 controls only a subset of the genes in the BDSF regulon in B. cenocepacia and proposed the existence of further sensing mechanisms for BDSF.

Although additional sensing mechanisms might be involved in the perception of DSF family signals, the RpfC-RpfG system serves as a major sensing system for DSF family signals in $X$. citri subsp. citri. The comparison of the RpfF, RpfC, and RpfG regulons revealed the conserved core gene group controlled by RpfF, RpfC, and RpfG in the exponential and stationary phases (Fig. 2B). The expression of the genes in the core group exhibits alterations in the same direction in all three mutants compared with the wild-type strain (Tables 1 and 2). The finding indicates that RpfF, RpfC, and RpfG exert the same effects on gene expression and are involved in the same signaling pathway. Furthermore, the majority of the genes that belonged to any two of the three regulons also belonged to the third regulon based on the application of a slightly relaxed stringency in the cut-off determination and showed altered expression in the same direction in all three mutants. Thus, we extended the core group to include these genes and designated it as an extended core group. The extended core group is controlled by all three QS components and includes genes involved in chemotaxis and flagellar biosynthesis, genes encoding extracellular enzymes, and genes encoding adhesins (Tables 1 and 2). The similar motility, protease production, and pelleting phenotypes of the $r p f F, r p f C$, and $r p f G$ mutants compared with the wild-type further supported the regulation of these functions by RpfF, RpfC, and RpfG. Overall, these findings indicate that RpfC-RpfG is the major sensory system of DSF family signalmediated QS in $X$. citri subsp. citri.

How does DSF family signal-mediated QS regulate diverse biological functions? Recent studies have advanced our understanding of this QS regulatory pathway. The interaction of the HD-GYP domain of RpfG with a subset of GGDEF domaincontaining proteins, which generally influence c-di-GMP levels, suggests the involvement of a few different downstream pathways in controlling subsets of QS-regulated functions. One pathway was shown to involve binding of c-di-GMP to the protein Clp and preventing it from regulating a subset of the DSF regulon genes (He et al. 2007). Another pathway was shown to involve RpfG interacting with two GGDEF proteins, XAC0258 and XAC0424, in X. citri subsp. citri (Andrade et al. 2006) and their homologues XC_0249 and XC_0420 in X. campestris pv. campestris (Ryan et al. 2010). XC_0249 and XC_0420 have been revealed to control motility but not other DSF-mediated phenotypes (Ryan et al. 2010). Notably, the expression of XAC0424 was up-regulated by RpfG in the exponential phase in this study. In addition to these two pathways, our data support the interaction of RpfC-RpfG with the NtrBNtrC complex, as previously demonstrated in $X$. citri subsp. citri (Andrade et al. 2006). NtrC contains ATP-dependent $\sigma^{54}$ activating and DNA-binding domains which interact with the RpfG HD-GYP domain. In V. harveyi and V. cholera, the NtrClike $\sigma^{54}$ activator (LuxO) and $\sigma^{54}$ are involved in QS (Lenz et al. 2004). In this study, the expression of $\sigma^{54}$ (XAC1969) was up-regulated by all three QS components in both growth

Table 2. (continued from preceding page)

\begin{tabular}{|c|c|c|c|c|c|c|}
\hline \multirow[b]{2}{*}{ Locus tag } & \multicolumn{3}{|c|}{$\log _{2}$-fold change ${ }^{a}$} & \multirow[b]{2}{*}{ Gene } & \multirow[b]{2}{*}{ Description } & \multirow[b]{2}{*}{$\mathrm{JCVI}^{\mathrm{c}}$} \\
\hline & rpfC/W St & rpfF/W St & rpfG/W St & & & \\
\hline XAC3726 & -2.20 & -1.56 & -1.03 & - & Hypothetical protein & Unclassified \\
\hline XAC0067 & -1.45 & -1.47 & -1.13 & $m d p B$ & Microcystin dependent protein & Unclassified \\
\hline XAC0066 & -1.27 & -1.46 & -1.18 & - & Microcystin dependent protein & Unclassified \\
\hline \multicolumn{7}{|c|}{ RpfF and RpfG only } \\
\hline XAC2922 & NS & -1.32 & -1.53 & hrpW & HrpW protein & Cell envelope \\
\hline XAC1813 & NS & 1.29 & 1.38 & hmsH & $\mathrm{HmsH}$ protein & Cell envelope \\
\hline XAC $3354 *$ & NS & 2.03 & 1.74 & ompW & Outer membrane protein $\mathrm{W}$ & Cell envelope \\
\hline XAC1951* & NS & -1.46 & -1.11 & fliI & Flagellar protein & Cellular processes \\
\hline XAC1988 & NS & 1.55 & 1.44 & $f \lg A$ & Flagellar basal body P-ring biosynthesis protein FlgA & Cellular processes \\
\hline XAC1955 & NS & 1.94 & 1.78 & fliE & Flagellar protein & Cellular processes \\
\hline XAC1948 & NS & 2.16 & 1.81 & fliL & Flagellar protein & Cellular processes \\
\hline XAC2028* & NS & -1.11 & -1.68 & $f d h$ & Glutathione-dependent formaldehyde dehydrogenase & Energy metabolism \\
\hline XAC2336 & NS & 1.72 & 1.57 & cydA & Cytochrome D ubiquinol oxidase subunit I & Energy metabolism \\
\hline XAC3776 & NS & -1.10 & -2.16 & - & Hypothetical protein & Hypothetical proteins \\
\hline XAC2026* & NS & -1.20 & -1.67 & - & Hypothetical protein & Not in JCVI \\
\hline XAC2027* & NS & -1.12 & -1.61 & - & Hypothetical protein & Not in JCVI \\
\hline XAC $3715 *$ & NS & -1.12 & -1.53 & - & Hypothetical protein & Not in JCVI \\
\hline XAC1928* & NS & -1.49 & -1.53 & - & Hypothetical protein & Not in JCVI \\
\hline $\mathrm{XAC} 2787 *$ & NS & -1.60 & -1.32 & - & Hypothetical protein & Not in JCVI \\
\hline XAC $3085 *$ & NS & -1.03 & -1.23 & - & Hypothetical protein & Not in JCVI \\
\hline XAC $3787 *$ & NS & -1.40 & -1.16 & - & Hypothetical protein & Not in JCVI \\
\hline XAC2370* & NS & -1.42 & -1.08 & - & Hypothetical protein & Not in JCVI \\
\hline XAC $3523 *$ & NS & 1.88 & 1.58 & - & Hypothetical protein & Not in JCVI \\
\hline $\mathrm{XAC} 1512 *$ & NS & -1.20 & -1.41 & - & Serine peptidase & Protein fate \\
\hline XAC2151* & NS & -1.79 & -1.08 & yapH & YapH protein & Protein fate \\
\hline XAC1328* & NS & -1.17 & -1.18 & - & Hypothetical protein & Regulatory functions \\
\hline XAC1812 & NS & 1.33 & 1.40 & $h m s F$ & HmsF protein & Regulatory functions \\
\hline XAC $1969 *$ & NS & -1.07 & -1.11 & rpoN & RNA polymerase $\sigma^{54}$ factor & Transcription \\
\hline \multicolumn{7}{|c|}{ RpfC and RpfF only } \\
\hline XAC4199* & -1.47 & -1.46 & NS & - & Polyvinylalcohol dehydrogenase & Unclassified \\
\hline XAC1953* & -1.09 & -1.45 & NS & fliG & Flagellar protein & Cellular processes \\
\hline XAC0661* & -1.18 & -1.38 & NS & peh-1 & Endopolygalacturonase & Cell envelope \\
\hline XAC3727 & -1.27 & -1.24 & NS & - & Hypothetical protein & Not in JCVI \\
\hline XAC $3725 *$ & -1.97 & -1.22 & NS & - & Hypothetical protein & Mobile \\
\hline \multicolumn{7}{|c|}{ RpfC and RpfG only } \\
\hline XAC $3966^{*}$ & -1.09 & NS & -1.50 & - & Hypothetical protein & Not in JCVI \\
\hline
\end{tabular}


phases. Furthermore, insertion mutation of $\sigma^{54}$ (XAC1969) affected the biofilm formation of $X$. citri subsp. citri ( $\mathrm{Li}$ and Wang 2011), suggesting that the NtrB-NtrC complex and $\sigma^{54}$ might regulate QS-regulated biofilm formation in $X$. citri subsp. citri.

Comparison of the three regulons revealed that there are a large number of unique genes in the RpfG regulon that were not regulated by $\mathrm{RpfC}$ and $\mathrm{RpfF}$, including genes encoding transporters such as iron transporters, genes encoding outer membrane proteins such as type $\mathrm{V}$ secretion system adhesins, genes involved in energy metabolism, genes encoding T3SS translocon, and regulatory genes (Fig. 2B). The partial overlap of the RpfG regulon with the RpfF regulon suggests that the regulatory role of RpfG in $X$. citri subsp. citri is not restricted to the transduction of the DSF family signals. In addition to the GGDEF proteins and NtrC mentioned above, RpfG also physically interacts with other proteins, such as a general stress protein XAC2369, an Hpr kinase XAC2975, and a putative polysaccharide deacetylase HmsF (Andrade et al. 2006). These protein-protein interactions are another line of evidence indicating that RpfG might be involved in other regulatory pathways. The influence on the expression of genes encoding transporters suggests that RpfG may coordinate with unknown sensors or other proteins in the transduction of external environmental signals. This may be related to the adaption to environmental changes, such as iron concentration and nutrient availability. Our previous transcriptome study of the HrpG regulon revealed that the expression of $r p f G$ is repressed by the virulence regulator $\mathrm{HrpG}$ at the stationary phase, suggesting the involvement of RpfG in adaptation to the different infection stages (Guo et al. 2011). It is not clear how X. citri subsp. citri coordinates RpfG and HrpG during citrus canker infection. However, the few genes encoding the T3SS translocon and effectors ( $h r c C$, hrcJ, hrpB1, hrpB2, hrpB4, hrpB5, hpal, $h p a B$, and $a v r X a c E 1)$ up-regulated only by RpfG may account for the lower virulence of the $r p f G$ mutant than that of the $r p f F$ and $r p f C$ mutants in citrus canker infection (Fig. 1).

RpfC may play a role in the regulatory pathway other than transduction of DSF signals. Interestingly, the LuxR-type receptors were reported to be activated by diketopiperazines in addition to AHL family signals in $P$. aeruginosa and multiple gram-negative bacteria (Holden et al. 1999). In total, the RpfC regulon includes only 21 and 4 genes in the exponential and stationary phases, respectively, that are distinct from in the other regulons (Fig. 2). The unique genes controlled by RpfC alone include $c z c D$ encoding a heavy metal transporter, genes associated with energy metabolism, and genes involved in protein fate. This may suggest that the RpfC participates in bacterial adaptation to the environment through an unknown pathway. The yeast two-hybrid assay revealed that RpfC interacts with RimM; XAC3455, which is 2-isopropylmalate synthase;

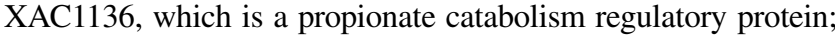
Xac1282, which is a two-component sensor histidine kinase; AvrBs2; and CMF (XAC0330), which is a conditioned medium factor (Andrade et al. 2006). RpfC interaction with one or more of these proteins could lead to a pathway independent of QS, such as an interaction with CMF. CMF was first found as a glycoprotein that was secreted under conditions of nutritional stress and served as a QS signal in Dictyostelium discoideum (Deery and Gomer 1999). A CMF homolog in X. citri subsp. citri contains a putative signal sequence and could be secreted to the periplasm or be bound to the inner membrane, implying that $\mathrm{CMF}$ could interact with $\mathrm{RpfC}$ to alter gene regulation (Andrade et al. 2006).

In conclusion, we have significantly advanced the understanding of DSF-mediated QS regulation by characterizing the $\mathrm{RpfC}$ and RpfG regulons in addition to the RpfF regulon. The comparison of these three regulons led to the identification of a core group of genes controlled by all three QS components, suggesting that the RpfC-RpfG two-component system is a
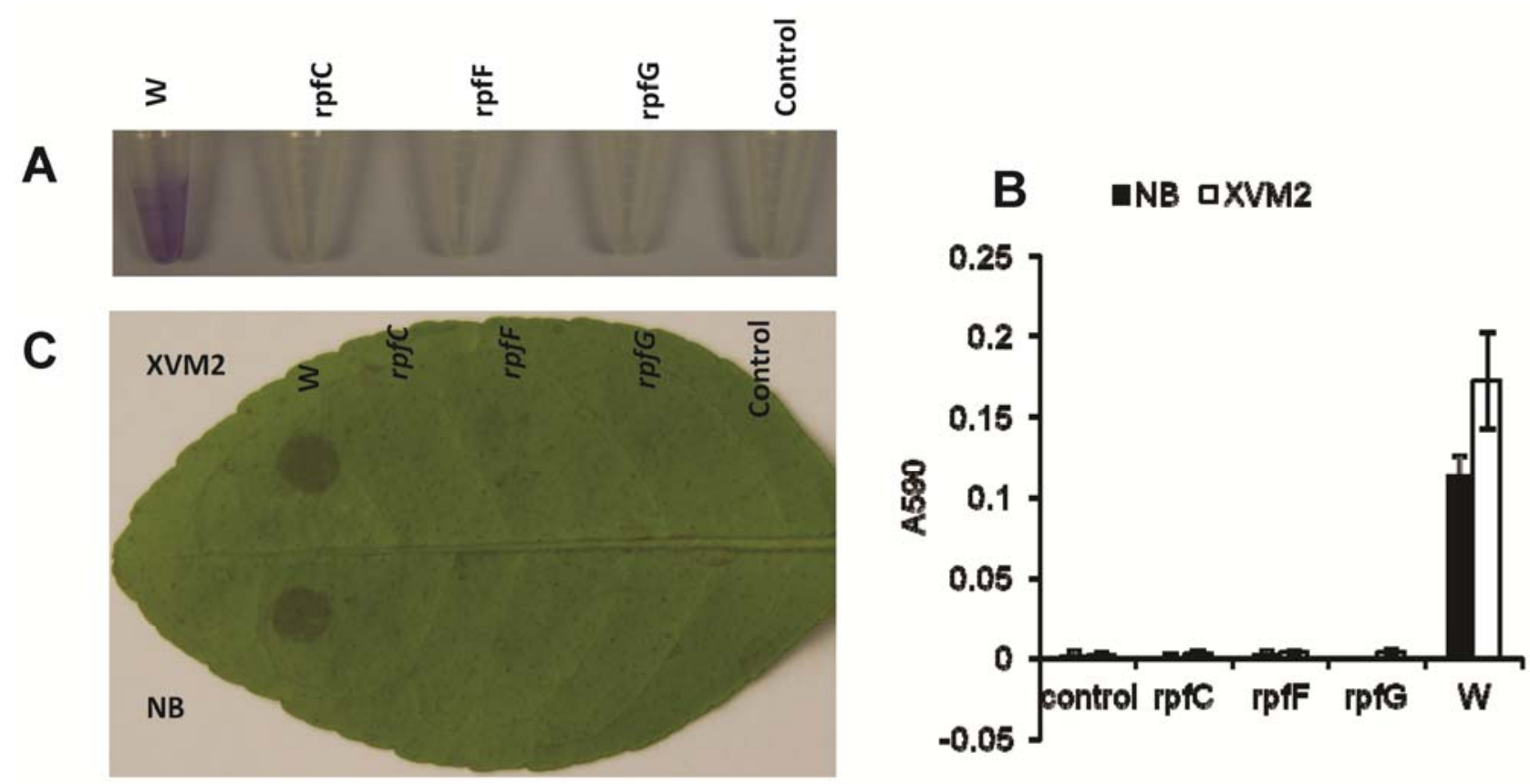

Fig. 3. Mutations in $r p f F$, rpfC, or $r p f G$ reduced the attachment of Xanthomonas citri subsp. citri to abiotic and biotic surfaces. A, Attachment of strains grown in XVM2 media to a polypropylene surface. Bacteria grown in nutrient broth (NB) showed similar results (data not shown). B, Quantification of bacterial attachment to polypropylene surfaces. Columns represent the mean of crystal violet staining measured spectrophotometrically (A590 nm) and error bars are standard deviations; represents the strains grown in NB and $\square$ represents the strains grown in XVM2. Means were calculated using 10 tubes for each strain. The assay was performed three times independently, and the representative results from one experiment are shown. $\mathbf{C}$, Attachment to abaxial surfaces of Duncan grapefruit leaves of strains grown in NB or XVM2 media. The assay was performed three times with six leaves each time, and similar results were obtained. Phosphate buffer ( $\mathrm{pH} 7.0)$ was used as the negative control in all assays. 
major and conserved signal perception and transduction system for DSF family signal-mediated QS in X. citri subsp. citri. The unique genes controlled by $\mathrm{RpfF}$ alone indicate the complexity of the QS pathway and the involvement of additional sensory mechanisms in $X$. citri subsp. citri. The unique genes controlled by RpfC and RpfG support the possibility that RpfC and RpfG play broader roles in gene regulation beyond transduction of QS signals.

\section{MATERIALS AND METHODS}

\section{Bacterial strains and growth conditions.}

All of the strains used in this study are listed in Supplementary Table S5. X. citri subsp. citri mutant strains were generated in this study as described below. The wild-type strain 306 (rifampicin resistant) (da Silva et al. 2002) and the mutant strains were routinely grown in NB, on nutrient agar (NA), or in nutrient yeast glycerol (NYG) medium (Daniels et al. 1984) at $28^{\circ} \mathrm{C}$. The composition of XVM 2 medium is described elsewhere (Wengelnik et al. 1996). E. coli strains were grown in Luria-Bertani (LB) medium at $37^{\circ} \mathrm{C}$. Antibiotics were used at the following concentrations: rifampicin (Rif), $50 \mu \mathrm{g} / \mathrm{ml}$; kanamycin (Kn), $50 \mu \mathrm{g} / \mathrm{ml}$; ampicillin (Ap), $50 \mu \mathrm{g} / \mathrm{ml}$; spectinomycin $(\mathrm{Sp}), 50 \mu \mathrm{g} / \mathrm{ml}$; gentamicin $(\mathrm{Gm}), 5 \mu \mathrm{g} / \mathrm{ml}$; and chloramphenicol $(\mathrm{Cm}), 35 \mu \mathrm{g} / \mathrm{ml}$.

\section{Construction of strains with mutations in genes involved in DSF-mediated QS signaling.}

To construct the $r p f F$ deletion mutant, the 1,610-bp fragment containing the entire $r p f F$ gene was amplified using genomic DNA from $X$. citri subsp. citri 306 as a template and the primers rpfFF and rpfFR (Supplementary Table S6). The fragment was cloned into a pGEM-T easy vector, resulting in the construct pGEM-rpfF. After digestion with AgeI and KpnI, the construct pGEM-rpfF was blunt ended using T4 DNA polymerase and self-ligated and denoted pGEM- $\Delta$ rpfF. From pGEM- $\Delta \mathrm{rpfF}$, an ApaI-SpeI fragment containing the $r p f F$ gene with the internal deletion was transferred into ApaI-XbaIdigested pOK 1 , resulting in pOK- $\Delta \mathrm{rpfF}$. The construct pOK$\Delta \mathrm{rpfF}$ was sequenced to confirm the deletion, before conjugation. E. coli DH5 $\alpha \lambda$ PIR (Huguet et al. 1998) were transformed with pOK- $\Delta \mathrm{rpfF}$, which was subsequently transferred to $X$. citri

\section{A}
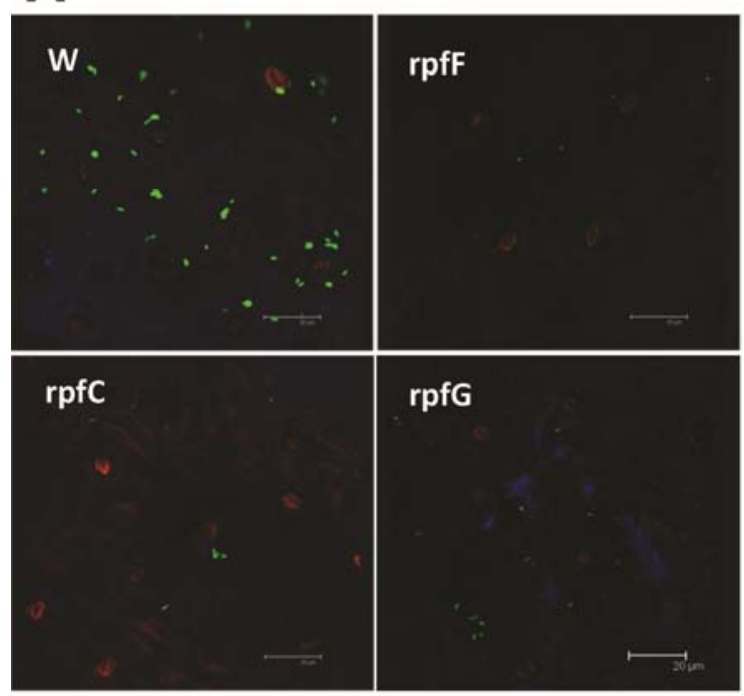

C

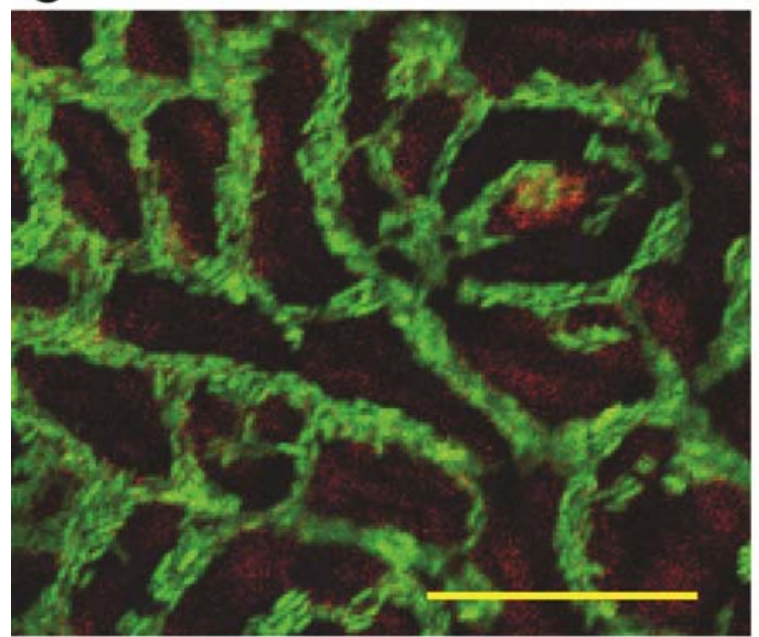

B
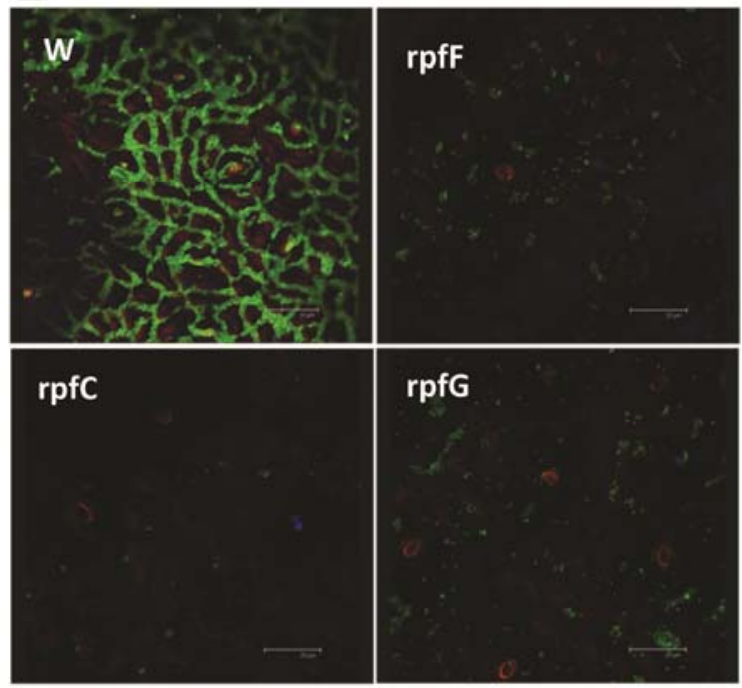

D
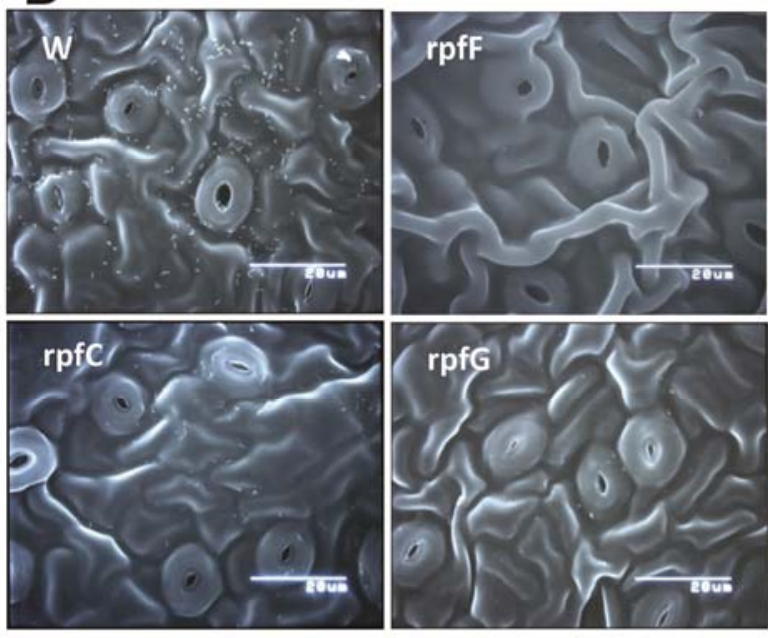

Fig. 4. Microscopic analysis of bacterial attachment on abaxial surfaces of Duncan grapefruit leaves. A, B, and C, Green fluorescent protein (GFP)-labeled stains grown in XVM2 were used in confocal laser scanning microscopy analysis. A, Bacterial attachment to leaves after $1 \mathrm{~h}$ of incubation. B, Bacterial attachment to leaves after $6 \mathrm{~h}$ of incubation. C, Zoomed-in image of GFP-labeled wild-type strain attached to leaves after $6 \mathrm{~h}$ of incubation. D, Scanning electron microscopy analysis of bacterial attachment to a leaf surface after $6 \mathrm{~h}$ of incubation. Three independent experiments were performed for each strain, and similar results were obtained. Scale bars in all images represent $20 \mu \mathrm{m}$. 
subsp. citri 306 by triparental mating with a helper E. coli strain containing pRK2013 (Swarup et al. 1991). Transconjugants were selected on NYG medium supplemented with Rif and Sp. Positive colonies were replicated on NA plates supplemented with $5 \%$ (wt/vol) sucrose, Sp, and Rif, as well as NA plates containing only Rif. The sucrose-sensitive colonies were selected from NA plates containing Rif and then dilution plated onto NA containing Rif and 5\% sucrose to select for the resolution of the construct by a second cross-over event. The resultant markerless deletion mutant of $r p f F$ was confirmed by PCR and sequencing.

To construct the rpfC deletion mutant of $X$. citri subsp. citri, the 3,017-bp fragment containing the entire $r p f C$ gene was amplified using genomic DNA from $X$. citri subsp. citri 306 as a template and the primers $\mathrm{rpfCF}$ and $\mathrm{rpfCR}$, and then cloned into a pGEM-T easy vector, resulting in pGEM-rpfC. The construct pGEM-rpfC was digested by BstEII to remove 1,116-bp from the interior of $r p f C$ and then self-ligated and denoted pGEM- $\Delta$ rpfC. An ApaI-SpeI fragment containing $r p f C$ with the internal deletion was transferred from pGEM- $\Delta$ rpfC into ApaI-XbaI-digested pOK1, generating pOK- $\Delta \mathrm{rpfC}$. The deletion construct pOK- $\Delta$ rpfC was transferred into $X$. citri subsp. citri 306 by triparental mating, and a deletion mutant of $r p f C$ was selected using the method described above.

The in-frame deletion mutant of $r p f G$ was constructed as follows. The 2,037-bp fragment containing the entire $r p f G$ gene was amplified using genomic DNA from $X$. citri subsp. citri 306 as a template and the primers rpfGF and rpfGR, and then cloned into a pGEM-T easy vector, resulting in pGEMrpfG. The pGEM-rpfG was digested by BssHII to remove 648 bp from the interior of $r p f G$ and then self ligated to form pGEM- $\Delta$ rpfG. An ApaI-SpeI fragment containing $r p f G$ with the in-frame deletion was transferred from pGEM- $\Delta$ rpfG into an $A p a \mathrm{I}-X b a \mathrm{I}$-digested pOK1 to generate pOK- $\Delta \mathrm{rpfG}$. The deletion construct $\mathrm{pOK}-\Delta \mathrm{rpfG}$ was transferred into $X$. citri subsp. citri 306 by triparental mating, and the rpfG deletion mutant was selected using the method described above.

\section{Complementation of the $r p f F, r p f C$, and $r p f G$ mutants.}

To generate the complementation plasmid for the $r p f F$ mutant, the fragment containing the entire $r p f F$ gene and its promoter was amplified using genomic DNA from $X$. citri subsp. citri 306 as a template and the primers rpfFF and rpfFR. The fragment was cloned into a PCR 2.1-TOPO vector, resulting in the construct PCR-rpfF. The HindIII-XbaI fragment containing the $r p f F$ gene from PCR-rpfF was blunt ended by T4 DNA polymerase and then cloned into pUFR053 that had been digested by HindIII, blunt ended, and treated with calf intestinal alkaline phosphatase. The derivative construct, p53-rpfF, was transferred into the $r p f F$ mutant by triparental mating. The transconjugants were selected on NA with Rif and Gm.

To construct the complementation plasmid for the rpfC mutant, the entire $r p f C$ gene was amplified from genomic DNA of $X$. citri subsp. citri 306 using PCR with the primers rpfC$\mathrm{KpnF}$ and rpfC-KpnR, which contain a $K p n I$ restriction site. The fragment was cloned into a PCR 2.1-TOPO vector, resulting in PCR-rpfC. The KpnI-digested fragment containing the $r p f C$ gene was transferred from PCR-rpfC into the KpnI site of pUFR053. The derivative constructs were sequenced to confirm the orientation of $r p f C$ insertion. The construct containing the $r p f C$ gene in the same orientation as the vector lac $Z$ and driven by lac promoter was selected as p53-rpfC. The p53rpfC was transferred into the $r p f C$ mutant by triparental mating and selected on NA with Rif and Gm.

To construct the complementation plasmid for the $r p f G$ mutant, an EcoRI fragment containing $r p f G$ and its promoter was transferred from pGEM-rpfG and ligated into the EcoRI site of
pUFR034, resulting in p34-rpfG. The construct p34-rpfG was transferred into the $r p f G$ mutant by triparental mating and selected on NA with Kn.

\section{RNA extraction.}

Individual bacterial colonies were selected and grown in $5 \mathrm{ml}$ of $\mathrm{NB}$ at $28^{\circ} \mathrm{C}$ for $24 \mathrm{~h}$ with shaking and then transferred into 50 $\mathrm{ml}$ of NB for overnight incubation. The bacterial cultures in the exponential phase were centrifuged and washed with XVM2 medium once, and inoculated in the XVM2 medium with an initial concentration of optical density at $600 \mathrm{~nm}\left(\mathrm{OD}_{600}\right)=0.03$. Bacteria were grown in XVM2 medium with constant shaking at $200 \mathrm{rpm}$ and $28^{\circ} \mathrm{C}$, and culture samples were collected at 11 and $25 \mathrm{~h}$, according to the growth curve in XVM2. Four biological replicates were used for each strain per time point. RNA was stabilized immediately by mixing bacterial culture with two volumes of RNAprotect bacterial reagent (Qiagen, Valencia, CA, U.S.A.) and incubation at room temperature for $5 \mathrm{~min}$. Bacterial cells were centrifuged at $5,000 \times g$ for $10 \mathrm{~min}$, and cell pellets were used for RNA extraction.

Cell pellets were treated with lysozyme and proteinase $\mathrm{K}$ for 15 min, and RNA extractions were performed using an RNeasy Mini kit (Qiagen). Contaminating genomic DNA was removed from the RNA samples by treatment with a TURBO DNA-free kit (Ambion, Austin, TX, U.S.A.). The RNA quantity was initially determined on an ND-8000 NanoDrop spectrophotometer (NanoDrop Technologies, Wilmington, DE, U.S.A.), and the RNA quality was assessed using the Agilent 2100 bioanalyzer (Agilent Technologies, Palo Alto, CA, U.S.A.).

\section{Microarray hybridization.}

Microarray analysis using the Agilent microarray platform was performed at the Interdisciplinary Center for Biotechnology Research Microarray Core Facility, the University of Florida. Labeled cDNA was generated using a Fairplay III microarray labeling kit (Agilent Technologies). Total RNA input (5 $\mu \mathrm{g}$ ) was used to generate labeled cDNA according to the manufacturer's protocol. Briefly, cDNA was synthesized from $5 \mu \mathrm{g}$ of total RNA with AffinityScript $\mathrm{HC}$ and random primers, and then modified cDNA was labeled with either $\mathrm{Cy} 3$ or $\mathrm{Cy} 5$; labeled cDNA was purified following the manufacturer's instructions. The microarray analysis was performed using the Agilent $8 \times 15 \mathrm{~K} X$. citri subsp. citri genome array (Guo et al. 2011). Four independent biological replicates were performed for two time-point comparisons with a dye-swap design. A total of 300 ng of labeled cDNA per sample was used for the hybridization. A dye swap was performed to remove any bias from the labeling dyes. Hybridization was performed using the Gene Expression Hybridization Kit (Agilent Technologies) according to the user's manual and was done in a hybridization oven for $17.5 \mathrm{~h}$ at $65^{\circ} \mathrm{C}$. The arrays were washed according to the manufacturer's recommended protocols. Briefly, arrays were washed with Gene Expression Wash Buffer 1 containing 0.005\% Triton $\mathrm{X}-102$ for $1 \mathrm{~min}$ at room temperature, washed with $37^{\circ} \mathrm{C}$ Gene Expression Wash Buffer 2 containing $0.005 \%$ Triton X102 for $1 \mathrm{~min}$, and dried with Agilent Stabilization and Drying Solution. The arrays were scanned using a dual-laser DNA microarray scanner (Model G2505C) (Agilent Technologies). Data were extracted from scanned images using Feature Extraction 10.1.1.1 software (Agilent Technologies).

\section{Microarray data analysis and statistical methods.}

The raw data were imported into the $\mathrm{R}$ environment, and statistical tests were performed using BioConductor statistical software, which is an open-source and open-development software project for the analysis of microarray and other high- 
throughput data based primarily on the $\mathrm{R}$ programming language (Gentleman et al. 2004). Data preprocessing and normalization were performed using the Linear Models for Microarray Data (LIMMA) package (Smyth 2004). Raw mean signal intensities from all microarray spots were background corrected and normalized using a within-array lowess approach. $\log _{2}$-transformed values were used for statistical analysis. Histograms, box plots, and pairwise scatter plots were generated to examine the data quality and comparability. A linear modeling approach and the empirical Bayes statistics as implemented in the LIMMA package (Smyth 2004) were then employed for differential expression analysis. The $P$ values were adjusted using the Benjamini and Hochberg method, designated as the FDR (Benjamini and Hochberg 1995). Differentially expressed genes were ranked based on FDR, and genes with an FDR less than 0.01 and a minimum absolute value of a $\log _{2}$-fold change greater than 1 (equivalent to twofold) were considered as significantly differentially expressed. If a gene had three probes and only one was filtered, the gene was removed from further analysis. The $\log _{2}$-fold change values of the differentially expressed genes were averaged from the values of the two or three probes of the corresponding genes. Annotation for the differentially expressed genes was extracted from the Integrated Microbial Genome database and the JCVI database and manually verified.

Details of our microarray experiments and the MIAMEcompliant microarray data have been deposited in the Gene Expression Omnibus database, the National Center of Biotechnology Information (accession number GSE29877).

\section{Real-time two-step QRT-PCR.}

To verify the microarray result, QRT-PCR assays were conducted using the same set of RNA as for microarray analysis. The aliquoted RNA sample $(1 \mu \mathrm{g})$ used for microarray was reverse transcribed using a QuantiTect Reverse Transcription kit with random hexamer primers (Qiagen) for two-step QRTPCR. Gene-specific primers were designed to generate products 100 to $250 \mathrm{bp}$ in length from sequences on the $X$. citri subsp. citri genome, using DNASTAR software (DNASTAR, Madison, WI, U.S.A.). QRT-PCR was performed for all four biological replicates of the $r p f G$ mutant and the wild-type strain on a 7500 Fast Real-Time PCR System (Applied Biosystems, Foster City, CA, U.S.A.) using a QuantiTect SYBR Green PCR kit (Qiagen) following the manufacturer's instructions. $16 \mathrm{~S}$ rRNA was used as an endogenous control. The relative fold change of gene expression was calculated by using the formula $2^{-\triangle \Delta C T}$ (Livak and Schmittgen 2001). The values of fold change were $\log _{2}$ transformed to compare with the values generated from microarray analysis.

\section{Motility assays.}

The medium for motility assays was NB or XVM2 containing $0.7 \%$ agar. Bacteria were grown in NB overnight with shaking at $200 \mathrm{rpm}$, and then centrifuged, washed, and diluted to $\mathrm{OD}_{600}=$ 0.3 in sterile water. A $1-\mu l$ suspension was spotted on the center of plate, which was incubated at room temperature. The assay was repeated three times, independently, in quadruplicate.

\section{Protease activity test.}

To measure the activity of extracellular proteases produced by bacteria, bacterial cells were grown in $\mathrm{NB}$ at $28^{\circ} \mathrm{C}$ overnight with shaking at $200 \mathrm{rpm}$, then centrifuged, washed, and diluted to $\mathrm{OD}_{600}=0.3$ in sterile water. A $1-\mu \mathrm{l}$ suspension was spotted on a $5 \%$ skim-milk-containing NA plate, which was incubated at room temperature. The protease activity was detected as zones of hydrolysis around the colonies. The assay was repeated three times, independently, in quadruplicate.

\section{Pathogenicity assay.}

Pathogenicity assays were conducted in a quarantine greenhouse facility at the Citrus Research and Education Center, Lake Alfred, FL, U.S.A. Assays were performed using fully expanded, immature leaves of Duncan grapefruit (Citrus paradisi Macfadyen). The $X$. citri subsp. citri wild-type and mutant strains used in this assay were grown with shaking overnight at $28^{\circ} \mathrm{C}$ in $\mathrm{NB}$, centrifuged, and suspended in sterile tap water, and the concentrations were adjusted to $10^{8} \mathrm{CFU} / \mathrm{ml}$. For the pathogenicity assays, bacterial solutions of $10^{8}, 10^{5}$, or $10^{4}$ $\mathrm{CFU} / \mathrm{ml}$ were infiltrated into leaves with needleless syringes (Rybak et al. 2009; Viloria et al. 2004). The test was repeated three times, and similar results were obtained. Disease symptoms were photographed at 6,12 , and 18 DPI. For the lesion test, inoculated areas were marked on leaves and photographed on 18 DPI. Canker lesions from 10 inoculated leaves were quantified, and the inoculated areas were calculated using the program ImageJ version 1.44p (Abramoff et al. 2004). The PROC GLM procedure of SAS 9.2 (SAS Institute, Cary, NC, U.S.A.) was used to analyze the significance of difference in virulence among those inoculated strains.

To mimic the natural infection process of $X$. citri subsp. $c i$ tri, Duncan grapefruit leaves were inoculated with bacterial suspensions of $10^{8} \mathrm{CFU} / \mathrm{ml}$ by spraying on the abaxial surface. The inoculated plants were covered with plastic bags for $24 \mathrm{~h}$ to maintain $100 \%$ relative humidity and then kept in a greenhouse (approximately 50\% relative humidity) for the symptoms to develop.

\section{Attachment assays.}

To measure the level of cells adhered to an abiotic surface, overnight cultures of the wild-type, $r p f F, r p f C$, and $r p f G$ mutant strains of $X$. citri subsp. citri in NB or XVM2 medium were centrifuged to recover cell pellets, washed, and resuspended in $10 \mathrm{mM}$ phosphate buffer $(\mathrm{pH} 7.0)$ to $\mathrm{OD}_{600}=1.0\left(10^{9}\right.$ $\mathrm{CFU} / \mathrm{ml})$. Each bacterial suspension $(200 \mu \mathrm{l})$ was aliquoted into $1.5-\mathrm{ml}$ plastic microcentrifuge tubes and incubated for $6 \mathrm{~h}$ at $28^{\circ} \mathrm{C}$. The adhesion was monitored by staining the attached bacteria with $\mathrm{CV}$. Bacterial adhesion was measured after repetitive washing of the tubes to remove nonadherent cells and then staining with $0.1 \% \mathrm{CV}$ for $45 \mathrm{~min}$ at room temperature. Excess stain was removed by washing under running tap water, and the CV stain was solubilized by the addition of $250 \mu \mathrm{l}$ of $99 \%$ ethanol to each tube. The amount of retained CV was quantified with an Agilent $8453 \mathrm{UV}$-visible spectrophotometer at $590 \mathrm{~nm}$. The assay was repeated three times with 10 replicates each time.

To observe the bacterial adhesion to biotic surfaces, bacterial suspensions $\left(\mathrm{OD}_{600}=1.0\right)$ were prepared as described above. Bacterial suspension $(20 \mu \mathrm{l})$ was plated on the abaxial surface of detached Duncan grapefruit leaves, which were then incubated for $6 \mathrm{~h}$ in a moist chamber at $28^{\circ} \mathrm{C}$. Inoculated leaves were washed twice with sterile tap water and stained with CV as for the abiotic surfaces (Gottig et al. 2009).

To directly observe the bacterial adhesion to the leaf surface using a confocal laser-scanning microscope, bacteria were transformed with a constitutively GFP-expressing pUFZ75 plasmid (Zhang et al. 2009) by electroporation. No difference in growth or adhesion to leaf and polypropylene surfaces could be detected between GFP-labeled bacteria and those lacking the GFP-expressing plasmid. The bacterial suspension was prepared and dropped onto detached leaves as described above. The inoculated leaves were incubated in a moist chamber at $28^{\circ} \mathrm{C}$ and observed at 1 and $6 \mathrm{~h}$ postinoculation. After washing twice with sterile tap water, inoculated areas were dissected from the leaf for microscopic observation. Bacterial adhesion was visualized using a Leica TCS SL confocal laser-scanning micro- 
scope (Leica Microsystems Inc., Buffalo Grove, IL, U.S.A) with a $63 \times$ water objective in the microscope lab at the Citrus Research and Education Center, Lake Alfred, FL, U.S.A. Three excitation and emission lines were used in the observation, as follows: green (excitation $488 \mathrm{~nm}$ and emission 500 to $545 \mathrm{~nm}$ ) for the detection of GFP-labeled strains, red (excitation $543 \mathrm{~nm}$ and emission 600 to $630 \mathrm{~nm}$ ) for the detection of the cuticle, and blue (excitation $633 \mathrm{~nm}$ and emission 680 to $750 \mathrm{~nm}$ ) for the detection of chlorophyll. The assay was performed three times independently in quadruplicate.

To further compare the location of bacterial cells relative to leaf tissue, we used a scanning electron microscope (SEM) in the microscope lab at the Citrus Research and Education Center. The leaves, after inoculation with bacteria for $6 \mathrm{~h}$, were washed twice with sterile tap water, and inoculated areas were dissected from the leaf (approximately $0.5 \mathrm{~cm}^{2}$ ) and fixed in $3 \%$ glutaraldehyde in $0.1 \mathrm{M}$ phosphate buffer $(\mathrm{pH} 7.2)$ overnight. The fixed leaf discs were washed three times with $0.1 \mathrm{M}$ phosphate buffer ( $\mathrm{pH} 7.2$ ), postfixed in $2 \% \mathrm{OsO}_{4}$ in $0.1 \mathrm{M}$ phosphate buffer ( $\mathrm{pH} 7.2$ ) for $4 \mathrm{~h}$, and rinsed twice in $0.1 \mathrm{M}$ phosphate buffer ( $\mathrm{pH}$ 7.2). After rinsing, the leaf discs were subjected to dehydration in a sequence of ethanol solutions $(10,20,30,40,50,60,70,80,90$, and $100 \%)$ for 10 min each. The final wash in $100 \%$ ethanol was repeated three times. Leaf discs were critical-point dried in a LADD critical point dryer (LADD Research, Williston, VT, U.S.A.) and then fixed on stubs and coated with gold-palladium using a LADD sputter coater (LADD Research). SEM micrographs were taken using an SEM S-530 (Hitachi, Tokyo) at $20 \mathrm{kV}$. SEM analysis was performed twice, with six replicates for each sample.

\section{ACKNOWLEDGMENTS}

This work was supported by United States Department of AgricultureNIFA Special Citrus Canker Grant Project 78159.

\section{LITERATURE CITED}

Abramoff, M. D., Magelhaes, P. J., and Ram, S. J. 2004. Image processing with ImageJ. Biophotonics Int. 11:36-42.

Andrade, M. O., Alegria, M. C., Guzzo, C. R., Docena, C., Rosa, M. C., Ramos, C. H., and Farah, C. S. 2006. The HD-GYP domain of RpfG mediates a direct linkage between the Rpf quorum-sensing pathway and a subset of diguanylate cyclase proteins in the phytopathogen Xanthomonas axonopodis pv. citri. Mol. Microbiol. 62:537-551.

Barber, C. E., Tang, J. L., Feng, J. X., Pan, M. Q., Wilson, T. J., Slater, H., Dow, J. M., Williams, P., and Daniels, M. J. 1997. A novel regulatory system required for pathogenicity of Xanthomonas campestris is mediated by a small diffusible signal molecule. Mol. Microbiol. 24:555-566.

Benjamini, Y., and Hochberg, Y. 1995. Controlling the false discovery rate: A practical and powerful approach to multiple testing. J. R. Stat. Soc. B 57:289-300.

Boon, C., Deng, Y., Wang, L. H., He, Y., Xu, J. L., Fan, Y., Pan, S. Q., and Zhang, L. H. 2008. A novel DSF-like signal from Burkholderia cenocepacia interferes with Candida albicans morphological transition. ISME J. 2:27-36.

Colnaghi Simionato, A. V., da Silva, D. S., Lambais, M. R., and Carrilho, E. 2007. Characterization of a putative Xylella fastidiosa diffusible signal factor by HRGC-EI-MS. J. Mass Spectrom. 42:490-496.

Cubero, J., and Graham, J. H. 2002. Genetic relationship among worldwide strains of Xanthomonas causing canker in citrus species and design of new primers for their identification by PCR. Appl. Environ. Microbiol. 68:1257-1264.

Daniels, M., Barber, C., Turner, P., Sawczyc, M., Byrde, R., and Fielding, A. 1984. Cloning of genes involved in pathogenicity of Xanthomonas campestris pv. campestris using the broad host range cosmid pLAFR1. EMBO (Eur. Mol. Biol. Organ.) J. 3:3323-3328.

da Silva, A. C., Ferro, J. A., Reinach, F. C., Farah, C. S., Furlan, L. R., Quaggio, R. B., Monteiro-Vitorello, C. B., Van Sluys, M. A., Almeida, N. F., Alves, L. M., do Amaral, A. M., Bertolini, M. C., Camargo, L. E., Camarotte, G., Cannavan, F., Cardozo, J., Chambergo, F., Ciapina, L. P., Cicarelli, R. M., Coutinho, L. L., Cursino-Santos, J. R., El-Dorry, H., Faria, J. B., Ferreira, A. J., Ferreira, R. C., Ferro, M. I., Formighieri,
E. F., Franco, M. C., Greggio, C. C., Gruber, A., Katsuyama, A. M. Kishi, L. T., Leite, R. P., Lemos, E. G., Lemos, M. V., Locali, E. C., Machado, M. A., Madeira, A. M., Martinez-Rossi, N. M., Martins, E. C., Meidanis, J., Menck, C. F., Miyaki, C. Y., Moon, D. H., Moreira, L. M., Novo, M. T., Okura, V. K., Oliveira, M. C., Oliveira, V. R., Pereira, H. A., Rossi, A., Sena, J. A., Silva, C., de Souza, R. F., Spinola, L. A., Takita, M. A., Tamura, R. E., Teixeira, E. C., Tezza, R. I., Trindade dos Santos, M., Truffi, D., Tsai, S. M., White, F. F., Setubal, J. C., and Kitajima, J. P. 2002. Comparison of the genomes of two Xanthomonas pathogens with differing host specificities. Nature 417:459-463.

Deery, W. J., and Gomer, R. H. (1999) A putative receptor mediating celldensity sensing in Dictyostelium. J. Biol. Chem. 274:34476-34482.

Dharmadi, Y., and Gonzalez, R. 2004. DNA microarrays: Experimental issues, data analysis, and application to bacterial systems. Biotechnol. Prog. 20:1309-1324.

Fouhy, Y., Scanlon, K., Schouest, K., Spillane, C., Crossman, L., Avison, M. B., Ryan, R. P., and Dow, J. M. 2007. Diffusible signal factor-dependent cell-cell signaling and virulence in the nosocomial pathogen Stenotrophomonas maltophilia. J. Bacteriol. 189:4964-4968.

Gentleman, R. C., Carey, V. J., Bates, D. M., Bolstad, B., Dettling, M., Dudoit, S., Ellis, B., Gautier, L., Ge, Y., Gentry, J., Hornik, K., Hothorn, T., Huber, W., Iacus, S., Irizarry, R., Leisch, F., Li, C., Maechler, M., Rossini, A. J., Sawitzki, G., Smith, C., Smyth, G., Tierney, L., Yang, J. Y., and Zhang, J. 2004. Bioconductor: Open software development for computational biology and bioinformatics. Genome Biol. 5:R80.

Gottig, N., Garavaglia, B. S., Garofalo, C. G., Orellano, E. G., and Ottado, J. 2009. A filamentous hemagglutinin-like protein of Xanthomonas axonopodis pv. citri, the phytopathogen responsible for citrus canker, is involved in bacterial virulence. PLoS One 4:e4358. Published online.

Graham, J. H., Gottwald, T. R., Cubero, J., and Achor, D. S. 2004. Xanthomonas axonopodis pv. citri: Factors affecting successful eradication of citrus canker. Mol. Plant Pathol. 5:1-15.

Guo, Y., Figueiredo, F., Jones, J., and Wang, N. 2011. HrpG and HrpX play global roles in coordinating different virulence traits of Xanthomonas axonopodis pv. citri. Mol. Plant-Microbe Interact. 24:649-661.

He, Y. W., Wang, C., Zhou, L., Song, H., Dow, J. M., and Zhang, L. H. 2006a. Dual signaling functions of the hybrid sensor kinase RpfC of Xanthomonas campestris involved either phosphorelay or receiver domain-protein interaction. J. Biol. Chem. 281:33414-33421.

He, Y. W, Xu, M., Lin, K., Ng, Y. J., Wen, C. M., Wang, L. H., Liu, Z. D., Zhang, H. B., Dong, Y. H., Dow, J. M., and Zhang, L. H. 2006b. Genome scale analysis of diffusible signal factor regulon in Xanthomonas campestris pv. campestris: Identification of novel cell-cell communication-dependent genes and functions. Mol. Microbiol. 59:610-622.

He, Y. W., Ng, A. Y., Xu, M., Lin, K., Wang, L. H., Dong, Y. H., and Zhang, L. H. 2007. Xanthomonas campestris cell-cell communication involves a putative nucleotide receptor protein Clp and a hierarchical signalling network. Mol. Microbiol. 64:281-292.

He, Y. W., Wu, J., Cha, J. S., and Zhang, L. H. 2010. Rice bacterial blight pathogen Xanthomonas oryzae pv. oryzae produces multiple DSF-family signals in regulation of virulence factor production. BMC Microbiol. 10:187.

Holden, M. T., Ram Chhabra, S., de Nys, R., Stead, P., Bainton, N. J., Hill, P. J., Manefield, M., Kumar, N., Labatte, M., England, D., Rice, S., Givskov, M., Salmond, G. P. C., Stewart, G. S. A. B., Bycroft, B. W., Kjelleberg, S., and Williams, P. 1999 Quorum-sensing cross talk: Isolation and chemical characterization of cyclic dipeptides from Pseudomonas aeruginosa and other gram negative bacteria. Mol. Microbiol. 33:1254-1266.

Huang, T. P., and Wong, A. C. L. 2007. A cyclic AMP receptor proteinsregulated cell-cell communication system mediates expression of a FecA homologue in Stenotrophomonas maltophilia. Appl. Environ. Microbiol. 73:5034-5040.

Huguet, E., Hahn, K., Wengelnik, K., and Bonas, U. 1998. hpaA mutants of Xanthomonas campestris pv. vesicatoria are affected in pathogenicity but retain the ability to induce host-specific hypersensitive reaction. Mol. Microbiol. 29:1379-1390.

Lenz, D. H., Mok, K. C., Lilley, B. N., Kulkarni, R. V., Wingreen, N. S., and Bassler, B. L. 2004. The small RNA chaperone Hfq and multiple small RNAs control quorum sensing in Vibrio harveyi and Vibrio cholerae. Cell 118:69-82.

Li, J., and Wang, N. 2011. Genome-wide mutagenesis of Xanthomonas axonopodis pv. citri reveals novel genetic determinants and regulation mechanisms of biofilm formation. PLoS One 6:e21804. Published online.

Livak, K. J., and Schmittgen, T. D. 2001. Analysis of relative gene expression data using real-time quantitative PCR and the $2^{-\Delta \Delta C T}$ method. Methods 25:402-408.

McCarthy, Y., Yang, L., Twomey, K. B., Sass, A., Tolker-Nielsen, T., Mahenthiralingam, E., Dow, J. M., and Ryan, R.P. 2010. A sensor kinase recognizing the cell-cell signal BDSF (cis-2-dodecenoic acid) 
regulates virulence in Burkholderia cenocepacia. Mol. Microbiol. 77:1220-1236.

Nealson, K. H., and Hastings, J. W. 1979. Bacterial bioluminescence: Its control and ecological significance. Microbiol. Rev. 43:496-518.

Newman, K. L., Almeida, R. P., Purcell, A. H., and Lindow, S. E. 2004 Cell-cell signaling controls Xylella fastidiosa interactions with both insects and plants. Proc. Natl. Acad. Sci. U.S.A. 101:1737-1742.

Ryan, R. P., Fouhy Y., Lucey, J. F., Crossman, L. C., Spiro, S., He, Y. W. Zhang, L. H., Heeb, S., Camara, M., Williams, P., and Dow, J. M. 2006. Cell-cell signaling in Xanthomonas campestris involves an HD-GYP domain protein that functions in cyclic di-GMP turnover. Proc. Natl. Acad. Sci. U.S.A. 103:6712-6717.

Ryan, R. P., McCarthy, Y., Andrade, M., Farah, C. S., Armitage, J. P., and Dow, J. M. 2010. Cell-cell signal-dependent dynamic interactions between HD-GYP and GGDEF domain proteins mediate virulence in Xanthomonas campestris. Proc. Natl. Acad. Sci. U.S.A. 107:5989-5994.

Rybak, M., Minsavage, G. V., Stall, R. E., and Jones, J. B. 2009. Identification of Xanthomonas citri ssp. citri host specificity genes in a heterologous expression host. Mol. Plant Pathol. 10:249-262.

Schaad, N., Postnikova, E., Lacy, G., Sechler, A., Agarkova, I., Stromberg, P., Stromberg, V., and Vidaver, A. 2006. Emended classification of xanthomonad pathogens on citrus. Syst. Appl. Microbiol. 29:690-695.

Schuster, M., Lostroh, C. P., Ogi, T., and Greenberg, E. P. 2003. Identification, timing, and signal specificity of Pseudomonas aeruginosa quorum-controlled genes: A transcriptome analysis. J. Bacteriol. 185:20662079.

Siciliano, F., Torres, P., Sendín, L., Bermejo, C., Filippone, P., Vellice, G., Ramallo, J., Castagnaro, A., Vojnov, A., and Marano, M. R. 2006. Analysis of the molecular basis of Xanthomonas axonopodis pv. citri pathogenesis in Citrus lemon. Electron. J. Biotechnol. 9:200-204.

Slater, H., Alvarez-Morales, A., Barber, C. E., Daniels, M. J., and Dow, J. M. 2000. A two-component system involving an HD-GYP domain protein links cell-cell signalling to pathogenicity gene expression in Xanthomonas campestris. Mol. Microbiol. 38:986-1003.

Smyth, G. K. 2004. Linear models and empirical Bayes methods for assessing differential expression in microarray experiments. Stat. Appl. Genet. Mol. Biol. 3:Article 3. Published online.

Swarup, S., Feyter, D., R., Brlansky, R. H., and Gabriel, D. W. 1991. A pathogenicity locus from Xanthomonas citri enables strains from several pathovars of Xanthomonas campestris to elicit canker-like lesions on citrus. Phytopathology 81:802-809.

Tao, F., Swarup, S., and Zhang, L. H. 2010. Quorum sensing modulation of a putative glycosyltransferase gene cluster essential for Xanthomonas campestris biofilm formation. Environ. Microbiol. 12:3159-3170.

Vauterin, L., Hoste, B., Kersters, K., and Swings, J. 1995. Reclassification of Xanthomonas. Int. J. Syst. Bacteriol. 45:472-489.

Viloria, Z., Drouillard, D. L., Graham, J. H., and Grosser, J. W. 2004 Screening triploid hybrids of 'Lakeland' limequat for resistance to citrus canker. Plant Dis. 88:1056-1060.

Wagner, V. E., Bushnell, D., Passador, L., Brooks, A. I., and Iglewski, B. H. 2003. Microarray analysis of Pseudomonas aeruginosa quorumsensing regulons: Effects of growth phase and environment. J. Bacteriol. 185:2080-2095.

Wang, L. H., He, Y., Gao, Y., Wu, J. E., Dong, Y. H., He, C., Wang, S. X. Weng, L. X., Xu, J. L., Tay, L., Fang, R. X., and Zhang, L. H. 2004. A bacterial cell-cell communication signal with cross-kingdom structural analogues. Mol. Microbiol. 51:903-912.

Waters, C. M., and Bassler, B. L. 2005. Quorum sensing: Cell-to-cell communication in bacteria. Annu. Rev. Cell. Dev. Biol. 21:319-346.

Wengelnik, K., Marie, C., Russel, M., and Bonas, U. 1996. Expression and localization of HrpA1, a protein of Xanthomonas campestris pv. vesicatoria essential for pathogenicity and induction of the hypersensitive reaction. J. Bacteriol. 178:1061-1069.

Ye, R. W., Wang, T., Bedzyk, L., and Croker, K. M. 2001. Applications of DNA microarrays in microbial systems. J. Microbiol. Methods 47:257272.

Zhang, Y., Callaway, E. M., Jones, J. B., and Wilson, M. 2009. Visualisation of hrp gene expression in Xanthomonas euvesicatoria in the tomato phyllosphere. Eur. J. Plant. Pathol. 124:379-390.

Zhao, Y., Qian, G., Yin, F., Fan, J., Zhai, Z., Liu, C., Hu, B., and Liuao, F. 2011. Proteomic analysis of the regulatory function of DSF-dependent quorum sensing in Xanthomonas oryzae pv. oryzicola. Microb. Pathog. $50: 48-55$

\section{AUTHOR-RECOMMENDED INTERNET RESOURCES}

BioConductor websit: www.bioconductor.org

Gene Expression Omnibus (GEO) website: www.ncbi.nlm.nih.gov/geo

The Integrated Microbial Genome (IMG) Xanthomonas axonopodis pv. citri 306 genome database:

img.jgi.doe.gov/cgi-bin/w/main.cgi?section=TaxonDetail\&page=taxon Detail\&taxon_oid=637000342

The J. Craig Venter Institute (JCVI) Xanthomonas axonopodis pv. citri 306 genome database:

cmr.jcvi.org/tigr-scripts/CMR/GenomePage.cgi?database=ntxa01 